\title{
AN AVENUE TO THE SORDARIN CORE ADAPTABLE TO ANALOG SYNTHESIS
}

Huan Liang, Arnaud Schülé, Jean-Pierre Vors, Marco A. Ciufolini*

Department of Chemistry, The University of British Columbia, 2036 Main Mall, Vancouver, BC V6T 1Z1, Canada

\section{Supporting Information}




\section{Table of Contents}

Experimental Protocols

Synthesis and Characterization of Various Intermediates

Experimental protocols

Ketoester 11

Enone 10

S3

Ketoester 12

Aldehyde 13

Nitrile 14

S4

Aldehyde 15

Nitrile 16

Compound 18

Compound 19

Compound 20

Compound 21

S6

Ketoalcohol 22

Diketone 23

Ketone 24

Cyanoenone 25

S7

Cyanoalcohol 26

Diene 27

Compound 29

Silyl enol ether $\mathbf{3 0}$

Tricyclic ketone 33

Proton- and ${ }^{13} \mathrm{C}$ NMR spectra

Ketoester 11

S10

Enone 10

S11

Ketoester 12

S12

Aldehyde 13

$\mathrm{S} 13$

Nitrile 14

S14

Aldehyde 15

S15

Nitrile 16

$\mathrm{S} 16$

Compound 18

S17

Compound 19

$\mathrm{S} 18$

Compound 20

$\mathrm{S} 19$

Compound 21

S20

Ketoalcohol 22

S21

Diketone 23

S22

Ketone 24

S23

Cyanoenone 25

S24

Cyanoalcohol 26

S25

Diene 27

S25

Compound 29

S26

Silyl enol ether $\mathbf{3 0}$

S27

Cycloadduct 31

S28

Tricyclic ketone $\mathbf{3 3}$ 
Experimental protocols. Unless otherwise indicated, ${ }^{1} \mathrm{H}(300 \mathrm{MHz})$ and ${ }^{13} \mathrm{C}(75 \mathrm{MHz}) \mathrm{NMR}$ spectra were recorded at room temperature from $\mathrm{CDCl}_{3}$ solutions. Chemical shifts are reported as ppm on the $\delta$ scale and coupling constants, $J$, are in Hz. Multiplicies are described as s (singlet), $\mathrm{d} / \mathrm{dd} / \mathrm{ddd}$ (doublet / doublet of doublets / doublet of doublet of doublets), $\mathrm{t}$ (triplet), $\mathrm{q}$ (quartet), sept (septuplet), $\mathrm{m}$ (multiplet), and further qualified as app (apparent), b (broad), c (complex). All 2D NMR spectra were recorded at $400 \mathrm{MHz}\left({ }^{1} \mathrm{H}\right) / 100$ $\mathrm{MHz}\left({ }^{13} \mathrm{C}\right)$. Low- and high resolution mass spectra were obtained in the EI $(70 \mathrm{eV})$, CI (isobutane) or ESI modes, as indicated. Infrared spectra $\left(\mathrm{cm}^{-1}\right)$ were recorded as neat films. Chromatographic separations were effected over Fluka 60 silica gel. Analytical and preparative TLC utilized Analtech 250 and $1000 \mu$ silica gel plates, respectively, with fluorescent indicator. Melting points are uncorrected. All reagents and solvents were commercial products and used without further purification except THF (freshly distilled from $\mathrm{Na}$ /benzophenone under $\mathrm{Ar}$ ) and $\mathrm{CH}_{2} \mathrm{Cl}_{2}$ (freshly distilled from $\mathrm{CaH}_{2}$ under Ar). Anhydrous DMF and LHMDS solution were purchased from Aldrich and used as received. Commercial $n$-BuLi was titrated against $N$-benzylbenzamide in THF at $-78^{\circ} \mathrm{C}$ until persistence of a light blue color. Flash chromatography was performed on Silicycle $230-400$ mesh silica gel. All reactions were performed under dry $\mathrm{Ar}$ in flame or over dried flasks equipped with Teflon ${ }^{\mathrm{TM}}$ stirbars. All flasks were fitted with rubber septa for the introduction of substrates, reagents, and solvents via syringe.

Ketoester 11. A solution of 3-methoxy-cyclopent-2-ene-1-one (500 mg, $4.5 \mathrm{mmol})$ in THF $(1.5 \mathrm{~mL})$ was added dropwise to a cold $\left(-50^{\circ} \mathrm{C}\right)$ solution of LHMDS (commercial $1 \mathrm{M}$ soln. in

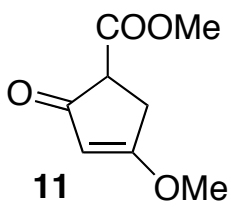
THF, $5.8 \mathrm{~mL}, 5.8 \mathrm{mmol}$,) in THF $(7.5 \mathrm{~mL})$, and the resulting mixture was stirred for $30 \mathrm{~min}$ at $-50{ }^{\circ} \mathrm{C}$. Neat $\mathrm{MeOOCCN}(0.4 \mathrm{~mL}, 4.9 \mathrm{mmol}$ : CAUTION: source of highly toxic HCN) was injected. The solution was stirred for $2.5 \mathrm{~h}$, during which time it was allowed to warm to RT, then it was cooled to $0{ }^{\circ} \mathrm{C}$, neutralized with aq. $1 \mathrm{~N} \mathrm{HCl}(10 \mathrm{~mL}$; CAUTION: formation of highly toxic $\mathrm{HCN})$, and extracted with EtOAc $(3 \times 15 \mathrm{~mL})$.

The combined extracts were washed with sat.'d aq. $\mathrm{NaCl}(10 \mathrm{~mL})$, dried $\left(\mathrm{Na}_{2} \mathrm{SO}_{4}\right)$ and evaporated. Chromatography of the residue (50:50 EtOAc/hexane) furnished $394 \mathrm{mg}$ (2.32 mmol, $52 \%$ ) of the known [(a) Irie, H.; Katakawa, J.; Tomita, M.; Mizuno, Y. Chem. Lett. 1981, 637. (b) Boschelli, D.; Smith, A. B., III; Stringer, O. D.; Jenkins, R. H., Jr.; Davis, F. A. Tetrahedron Lett. 1981, 22, 4385] $\beta$-ketoester 11. ${ }^{1} \mathbf{H}: 5.28(\mathrm{~s}, 1 \mathrm{H}) ; 3,87(\mathrm{~s}, 3 \mathrm{H}) ; 3.76(\mathrm{~s}, 3 \mathrm{H})$; $3.53(\mathrm{dd}, J=7.5,3.0,1 \mathrm{H}) ; 3.04(\mathrm{dd}, J=17.7,3.0,1 \mathrm{H}) ; 2.77(\mathrm{dd}, J=17.7,7.5,1 \mathrm{H}) .{ }^{13} \mathbf{C}$ : $198.3 ; 191.1 ; 169.9 ; 103.2 ; 59.6 ; 53.1 ; 51.7 ; 32.5$. HRCIMS: Calc. for $\mathrm{C}_{8} \mathrm{H}_{11} \mathrm{O}_{4}[\mathrm{M}+\mathrm{H}]^{+}$ 171.0657; found 171.0654 .

Enone 10. Neat $\mathrm{Me}_{2} \mathrm{SO}_{4}(4.5 \mathrm{~g}, 36.0 \mathrm{mmol}$; CAUTION: toxic, corrosive, cancer suspect agent) was added at RT to a vigorously stirred suspension of $8(5.0 \mathrm{~g}, 36.0 \mathrm{mmol})$ and $\mathrm{K}_{2} \mathrm{CO}_{3}$

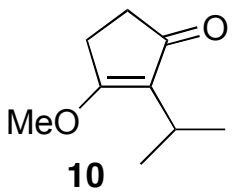
$(4.5 \mathrm{~g}, 36.0 \mathrm{mmol})$ in acetone $(60 \mathrm{~mL})$. The mixture was then heated to $60{ }^{\circ} \mathrm{C}$ for $8 \mathrm{~h}$ with continued stirring, then it was cooled and concentrated. The residue was partitioned between EtOAc $(10 \mathrm{~mL})$ and aq. $1 \mathrm{M} \mathrm{NaOH}(15 \mathrm{~mL})$, the layers were separated, and the aqueous phase was further extracted with EtOAc $(3 \times 30 \mathrm{ml})$. The combined extracts were washed with brine $(30 \mathrm{~mL})$, dried $\left(\mathrm{MgSO}_{4}\right)$ and concentrated. Chromatography of the residue (25\% EtOAc / hexanes) gave $5.5 \mathrm{~g}(35.0 \mathrm{mmol}, 99 \%)$ of $\mathbf{1 0}$ as an oil. ${ }^{1} \mathbf{H}: 3,91$ (s, $3 \mathrm{H}) ; 2.73$ (sept, $J=7,0,1 \mathrm{H}) ; 2.62(\mathrm{~m}, 2 \mathrm{H}) ; 2.39(\mathrm{~m}, 2 \mathrm{H}) ; 1.11(\mathrm{~d}, J=7.0,6 \mathrm{H}) .{ }^{13} \mathrm{C}: 204.8$; 184.6; $125.8 ; 56.5 ; 33.8 ; 24.4 ; 23.1 ; 20.4$. IR: 1682, 1621. HRCIMS: Calc. for $\mathrm{C}_{9} \mathrm{H}_{15} \mathrm{O}_{2}[\mathrm{M}+$ $\mathrm{H}]^{+} 155.1072$; found: 155.1078 . 
Ketoester 12. A solution of $\mathbf{1 0}(306 \mathrm{mg}, 2 \mathrm{mmol})$ in THF $(2 \mathrm{~mL})$ was added dropwise to a cold $\left(-78^{\circ} \mathrm{C}\right)$ solution of LHMDS $(2.1 \mathrm{~mL}$ of commercial $1 \mathrm{M}$ THF solution, $2.1 \mathrm{mmol}$, diluted an additional $2 \mathrm{~mL}$ of THF), and the mixture was stirred at -78<smiles>COC(=O)C1CC(=O)C(C(C)C)=C1OC</smiles>
${ }^{\circ} \mathrm{C}$ for $2 \mathrm{~h}$. Neat MeOOCCN (160 $\mu \mathrm{L}, 2 \mathrm{mmol}$; CAUTION: source of highly toxic $\mathrm{HCN}$ ) was injected and the solution was stirred $-78{ }^{\circ} \mathrm{C}$ for $30 \mathrm{~min}$. The reaction was quenched at $-78{ }^{\circ} \mathrm{C}$ by addition of aq. $1 \mathrm{~N} \mathrm{HCl}$ (4 mL; CAUTION: formation of HCN), allowed to warm to RT, and extracted with EtOAc $(3 \times 15 \mathrm{~mL})$. The combined extracts were washed with brine $(10 \mathrm{~mL})$, dried $\left(\mathrm{Na}_{2} \mathrm{SO}_{4}\right)$ and concentrated. Chromatography of the residue (50:50 EtOAc/hexanes) gave $340 \mathrm{mg}(81 \%)$ of $\mathbf{1 2}$ as an oil. ${ }^{1} \mathbf{H}: 3.90(\mathrm{~s}, 3 \mathrm{H}) ; 3.83(\mathrm{dd}, J=7.6,2.3,1 \mathrm{H}) ; 3.78(\mathrm{~s}, 3 \mathrm{H})$; 2.79 (sept, $J=6.7,1 \mathrm{H}) ; 2.72(\mathrm{~d}, J=7.4,1 \mathrm{H}) ; 2.47(\mathrm{dd}, J=17.8,2.3,1 \mathrm{H}) ; 1.14(\mathrm{~d}, J=6.8$, 6H). ${ }^{13}$ C: $202.2 ; 179.5 ; 172.1 ; 128.1 ; 57.4 ; 53.2 ; 42.7 ; 39.3 ; 23.4 ; 20.2$. IR: $1736,1702,1620$. HRCIMS: Calc. for $\mathrm{C}_{9} \mathrm{H}_{17} \mathrm{O}_{4}[\mathrm{M}+\mathrm{H}]^{+} 213.1127$; found 213.1131 .

Aldehyde 13. Neat DBU $(4 \mu \mathrm{L}, 24 \mu \mathrm{mol})$ was added to a cold $\left(0{ }^{\circ} \mathrm{C}\right) \mathrm{MeCN}(2.4 \mathrm{~mL})$ solution of 11 (204 mg, $1.20 \mathrm{mmol})$ and acrolein ( $90 \mu \mathrm{L}, 1.3 \mathrm{mmol}$; CAUTION: toxic, cancer<smiles>COC1=CC(=O)C(CCC=O)(C(C)=O)C1</smiles>
suspect agent). The solution was then warmed to RT, stirred for $3 \mathrm{~h}$, and finally diluted with EtOAc $(10 \mathrm{~mL})$. The mixture was sequentially washed with aq. sat.'d $\mathrm{NH} 4 \mathrm{Cl}(5 \mathrm{~mL})$ and aq. sat.'d $\mathrm{NaCl}(5 \mathrm{~mL})$, dried $\left(\mathrm{Na}_{2} \mathrm{SO}_{4}\right)$ and evaporated to afford $271 \mathrm{mg}$ of $13(1.2 \mathrm{mmol}, 100 \%)$. ${ }^{1} \mathrm{H}: 9.74(\mathrm{~s}, 1 \mathrm{H}) ; 5.27(\mathrm{~s}, 1 \mathrm{H}) ; 3.88(\mathrm{~s}, 3 \mathrm{H}) ; 3.71(\mathrm{~s}, 3 \mathrm{H}) ; 3.16(\mathrm{~d}, J=$

18.0, 1H); $2.55(\mathrm{~m}, 2 \mathrm{H}) ; 2.44(\mathrm{~d}, J=18.0,1 \mathrm{H}) ; 2.28(\mathrm{~m}, 1 \mathrm{H}) ; 2.15(\mathrm{~m}, 1 \mathrm{H}) .{ }^{13} \mathbf{C}: 201.3 ; 200.9$; 190.2; 171.4; 102.6; 59.6; 58.3; 53.3; 39.8; 38.9; 26.8. IR: 1731, 1698. HRCIMS: Calc. for $\mathrm{C}_{11} \mathrm{H}_{15} \mathrm{O}_{5}[\mathrm{M}+\mathrm{H}]^{+} 227.0919$; found 227.0920.

Nitrile 14. A mixture of 13 (70 mg, $301 \mu \mathrm{mol})$, acrylonitrile $(0.6 \mathrm{~mL}$; CAUTION: toxic, cancer suspect agent) and DABCO $(7 \mathrm{mg}, 62 \mu \mathrm{mol})$ was stirred at RT for 2 days, then it was<smiles>C=C(C#N)C(O)CCC1(C(=O)OC)CC(OC)=CC1=O</smiles>
concentrated. Chromatography of the residue (50:50 EtOAc/ hexanes) provided $49 \mathrm{mg}$ of $\mathbf{1 4}(176 \mu \mathrm{mol}, 57 \%) .{ }^{\mathbf{1}} \mathbf{H}: 6.02(\mathrm{dd}, J=17.0,2.0$, $2 \mathrm{H}) ; 5.28(\mathrm{~s}, 1 \mathrm{H}) ; 4.27(\mathrm{~m}, 1 \mathrm{H}) ; 3.90(\mathrm{~s}, 3 \mathrm{H}) ; 3.72(\mathrm{~s}, 3 \mathrm{H}) ; 3.19(\mathrm{~d}, J$ $=18.0,1 \mathrm{H}) ; 2.53(\mathrm{~d}, J=18.0,1 \mathrm{H}) ; 2.30-2.10(\mathrm{~m}, 2 \mathrm{H}) ; 1.95-1.60(\mathrm{~m}$, 3H). ${ }^{13} \mathrm{C}: 201.5 ; 190.9 ; 171.6 ; 130.8 ; 126.6 ; 117.4 ; 102.6 ; 71.9 ; 59.6$; 59.0; 53.3; 38.3; 30.9; 29.6. HRCIMS: Calc. for $\mathrm{C}_{14} \mathrm{H}_{18} \mathrm{NO}_{5}$ $280.1185[\mathrm{M}+\mathrm{H}]^{+}$; found 280.1183 .

Aldehyde 15. Neat DBU $(13 \mu \mathrm{L}, 87 \mu \mathrm{mol})$ was added to a cold $\left(0{ }^{\circ} \mathrm{C}\right)$ solution of $12(920 \mathrm{mg}$, $4.3 \mathrm{mmol})$ and acrolein ( $308 \mu \mathrm{l}, 4.6 \mathrm{mmol}$; CAUTION: toxic, cancer suspect agent) in MeCN

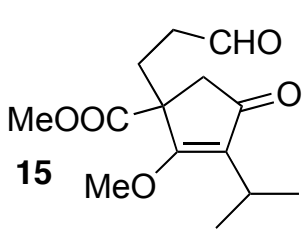

$(9 \mathrm{~mL})$.The mixture was stirred at $0^{\circ} \mathrm{C}$ for $30 \mathrm{~min}$, then at RT for $4 \mathrm{~h}$, and finally it was concentrated. The residue was treated with aq. sat'd. $\mathrm{NH}_{4} \mathrm{Cl}$ $(20 \mathrm{~mL})$ and extracted with EtOAc $(4 \times 10 \mathrm{~mL})$. The combined extracts were washed with brine $(15 \mathrm{~mL})$, dried $\left(\mathrm{MgSO}_{4}\right)$ and concentrated to afford crude 15 (1.1 g, 95\%), which was used without further purification. ${ }^{1} \mathbf{H}$ : 9.76 (s, $\left.1 \mathrm{H}\right) ; 3.99(\mathrm{~s}, 3 \mathrm{H}) ; 3.74$ (s, 3H); 2.99 (sept, $J=$

$6.8,1 \mathrm{H}) ; 2.69(\mathrm{~d}, J=17.8,1 \mathrm{H}) ; 2.48(\mathrm{~m}, 1 \mathrm{H}) ; 2.32-2.28(\mathrm{~m}, 3 \mathrm{H}) ; 2.23(\mathrm{~d}, J=17.7,1 \mathrm{H}) ; 1.23$ $(\mathrm{dd}, J=7.1,4.3,6 \mathrm{H}) .{ }^{13} \mathrm{C}: 202.8 ; 200.9 ; 180.2 ; 173.6 ; 126.6 ; 59.7 ; 53.1 ; 52.2 ; 45.3 ; 39.0$; 26.1; 24.5; 20.7; 20.4. IR: 1730, 1692, 1611. HRCIMS: Calc. for $\mathrm{C}_{14} \mathrm{H}_{21} \mathrm{O}_{5}[\mathrm{M}+\mathrm{H}]^{+}$ 269.1389; found 269.1390 . 
Nitrile 16. Method A. A solution of 15 (4.1 g, $15.2 \mathrm{mmol})$ and DABCO (341 $\mathrm{mg}, 3.0 \mathrm{mmol})$ in acrylonitrile (30 mL; CAUTION: toxic, cancer suspect agent) was stirred at RT for 2 days,

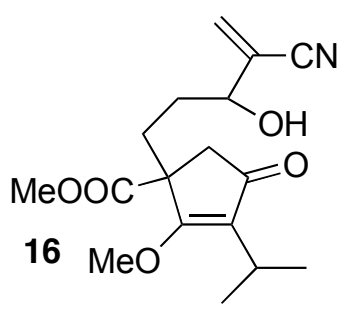
then additional DABCO (341 $\mathrm{mg}, 3.0 \mathrm{mmol}$ ) was added and the mixture was stirred at RT for another 2 days. The mixture was concentrated and the residue was chromatographed (50:50 EtOAc/hexanes) to give a nearly $1: 1$ mixture of diastereomers of $\mathbf{1 6}$ $(3.3 \mathrm{~g}, 68 \%)$ as an oil. Method B. A solution of $15(65 \mathrm{mg}, 242$ $\mu \mathrm{mol}), \mathrm{DABCO}(27 \mathrm{mg}, 242 \mu \mathrm{mol})$, triethanolamine $(16 \mu \mathrm{L}, 121$ $\mu \mathrm{mol})$ and $\mathrm{La}(\mathrm{OTf})_{3}(7 \mathrm{mg}, 12 \mu \mathrm{mol})$ in acrylonitrile $(0.5 \mathrm{~mL}$; CAUTION: see above) was stirred at RT for $11 \mathrm{~h}$, then it was concentrated. The residue was taken up with aq.sat'd. $\mathrm{NaHCO}_{3}(20$

$\mathrm{mL})$ and extracted with EtOAc $(3 \times 10 \mathrm{~mL})$. The combined extracts were washed with brine $(15 \mathrm{~mL})$, dried $\left(\mathrm{MgSO}_{4}\right)$ and concentrated. Chromatography of the residue $(50: 50$ EtOAc/hexanes) gave a nearly 65:35 mixture of diastereomers of $16(39 \mathrm{mg}, 50 \%)$ as an oil. ${ }^{1} \mathrm{H}: 6.04(\mathrm{~d}, J=10.2,2 \mathrm{H}) ; 4.29(\mathrm{~m}, 1 \mathrm{H}) ; 4.01(\mathrm{~d}, J=3.0,3 \mathrm{H}) ; 3.71(\mathrm{~s}, 3 \mathrm{H}) ; 3.01(\mathrm{~m}, 1 \mathrm{H})$; $2.69(\mathrm{dd}, J=17.8,3.5,1 \mathrm{H}) ; 2.30(\mathrm{~d}, J=17.7,1 \mathrm{H}) ; 2.05-1.98(\mathrm{~m}, 2 \mathrm{H}) ; 1.75-1.50(\mathrm{~m}, 2 \mathrm{H})$; 1.24 (m, 6H). ${ }^{13} \mathrm{C}: 203.7 ; 181.1 ; 180.8 ; 174.1 ; 174.0 ; 130.7 ; 126.9 ; 126.8 ; 126.7 ; 117.4$; $117.3 ; 72.0 ; 71.5 ; 59.9 ; 59.8 ; 52.7 ; 45.4 ; 45.3 ; 30.3 ; 30.1 ; 29.3 ; 28.8 ; 24.6 ; 20.9 ; 20.8$. IR: 3367, 2223, 1732, 1688, 1606. HRCIMS: Calc. for $\mathrm{C}_{17} \mathrm{H}_{24} \mathrm{NO}_{5}[\mathrm{M}+\mathrm{H}]^{+} 322.1654$; found: 322.1654 .

Compound 18. Neat TIPS-OTf $(2.7 \mathrm{~mL}, 11.2 \mathrm{mmol})$ was added to a cold $\left(0{ }^{\circ} \mathrm{C}\right)$ solution of 14 (1.3 g, $4.5 \mathrm{mmol})$ and Hünig base $(2 \mathrm{~mL}, 11.2 \mathrm{mmol})$ in $\mathrm{CH}_{2} \mathrm{Cl}_{2}(18 \mathrm{~mL})$, then the mixture

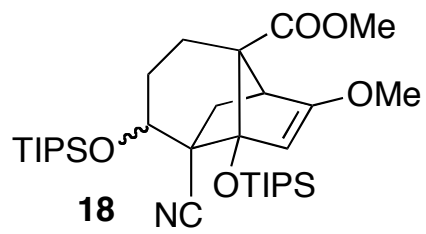
was allowed to warm to RT and stirred for $12 \mathrm{~h}$. The solution was diluted with a 3:1 mixture of pentane- $\mathrm{CH}_{2} \mathrm{Cl}_{2}(100 \mathrm{~mL})$, resulting in the appearance of a white precipitate that was filtered off. The organic filtrate was washed with aq. sat.'d $\mathrm{NaHCO}_{3}$, dried $\left(\mathrm{Na}_{2} \mathrm{SO}_{4}\right)$ and evaporated. Chromatography of the residue (5:95 EtOAc/hexanes) provided $\mathbf{1 8}(1.90 \mathrm{~g}, 3.2 \mathrm{mmol}, 72 \%)$ as a nearly 1:1 mixture of diastereomers. ${ }^{1} \mathbf{H}: 4.85-4.80(\mathrm{~m}, 2 \mathrm{H}) ; 4.13(\mathrm{t}, J=4.1,2 \mathrm{H}) ; 3.32(\mathrm{~s}, 3 \mathrm{H}) ; 3.25$ $(\mathrm{s}, 3 \mathrm{H}) ; 3.16(\mathrm{~s}, 3 \mathrm{H}) ; 3.13(\mathrm{~s}, 3 \mathrm{H}) ; 2.71(\mathrm{~d}, J=4.1,2 \mathrm{H}) ; 2.38(\mathrm{~d}, J=4.5,2 \mathrm{H}) ; 2.27(\mathrm{dd}, J=$ 13.6, 4.1, 2H); $2.17(\mathrm{~m}, 2 \mathrm{H}) ; 2.00-1.80(\mathrm{~m}, 6 \mathrm{H}) ; 1.50-0.90(\mathrm{~m}, 84 \mathrm{H}) .{ }^{13} \mathrm{C}: 174.0 ; 173.4$; $170.9 ; 169.5 ; 128.7 ; 123.6 ; 123.0 ; 96.6 ; 97.3 ; 91.6 ; 91.2 ; 76.0 ; 70.2 ; 66.5 ; 65.9 ; 56.9 ; 54.7$; $53.2 ; 51.8 ; 51.7 ; 47.2 ; 42.6 ; 33.3 ; 28.1 ; 27.9 ; 25.1 ; 19.5 ; 19.3 ; 18.8 ; 18.3 ; 14.6 ; 13.5 ; 13.1$. HRCIMS: Calc. for $\mathrm{C}_{32} \mathrm{H}_{58} \mathrm{NO}_{5} \mathrm{Si}_{2}[\mathrm{M}+\mathrm{H}]^{+}$592.3854; found 592.3859.

Compound 19. Neat TES-OTf $(190 \mu \mathrm{L}, 830 \mu \mathrm{mol})$ was added to a cold $\left(0^{\circ} \mathrm{C}\right) \mathrm{CH}_{2} \mathrm{Cl}_{2}(1.5$ $\mathrm{mL})$ solution of $\mathbf{1 6}(121 \mathrm{mg}, 380 \mu \mathrm{mol}, 1: 1$ mixture of diastereomers) and Hünig base (160

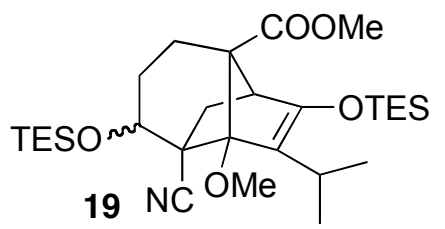

$\mu \mathrm{L}, 940 \mu \mathrm{mol})$. The solution was warmed to RT and stirred for 12 $\mathrm{h}$, then it was diluted with a 3:1 mixture of pentane / $\mathrm{CH}_{2} \mathrm{Cl}_{2}(10$ $\mathrm{mL})$, resulting in precipitation of a white solid which was filtered off. The filtrate was washed with aq. sat'd. $\mathrm{NaHCO}_{3}(3 \mathrm{~mL})$, dried $\left(\mathrm{Na}_{2} \mathrm{SO}_{4}\right)$ and concentrated. Chromatography of the residue (5:95 EtOAc/hexanes) gave $108 \mathrm{mg}(52 \%)$ of a nearly $1: 1$ mixture of diastereomers of 19 as an oil. ${ }^{1} \mathbf{H}: 4.39(\mathrm{~m}, 1 \mathrm{H}) ; 4.25(\mathrm{t}, J=7.6,1 \mathrm{H}) ; 3.88(\mathrm{~s}, 3 \mathrm{H}) ; 3.75(\mathrm{~s}$, $3 \mathrm{H}) ; 3.65(\mathrm{~s}, 3 \mathrm{H}) ; 3.61(\mathrm{~s}, 3 \mathrm{H}) ; 2.71-2.67(\mathrm{~m}, 2 \mathrm{H}) ; 2.51(\mathrm{~m}, 2 \mathrm{H}) ; 2.41(\mathrm{~m}, 2 \mathrm{H}) ; 2.17-1.87(\mathrm{~m}$, $8 \mathrm{H}) ; 1.70-1.40(\mathrm{~m}, 2 \mathrm{H}) ; 1.30(\mathrm{dd}, J=6.7,1.5,6 \mathrm{H}) ; 1.14(\mathrm{dd}, J=6.9,5.7,6 \mathrm{H}) ; 1.02-0.90(\mathrm{~m}$, $36 \mathrm{H}) ; 0.75-0.62(\mathrm{~m}, 24 \mathrm{H}) .{ }^{13} \mathrm{C}: 173.7 ; 173.6 ; 157.3 ; 154.9 ; 123.8 ; 123.5 ; 123.4 ; 122.0 ; 94.5$; 93.4; 74.8; 68.9; 66.5; 65.9; 58.6; 56.4; 56.1; 51.9; 48.8; 48.4; 47.9; 41.4; 32.8; 27.3; 27.2; 
25.6; 25.4; 22.4; 22.3; 20.6; 20.2; 6.8; 6.7; 6.6; 6.4; 5.5; 5.0; 4.8. HRCIMS: Calc. for $\mathrm{C}_{29} \mathrm{H}_{52} \mathrm{NO}_{5} \mathrm{Si}_{2}[\mathrm{M}+\mathrm{H}]^{+}$550.3384; found 550.3383.

Compound 20. Neat TBS-OTf $(147 \mu \mathrm{L}, 550 \mu \mathrm{mol})$ was added to a cold $\left(0^{\circ} \mathrm{C}\right) \mathrm{THF}(1.3 \mathrm{~mL})$ solution of $16(30 \mathrm{mg}, 93 \mu \mathrm{mol})$ and Hünig base $(140 \mu \mathrm{L}, 810 \mu \mathrm{mol})$. The solution was

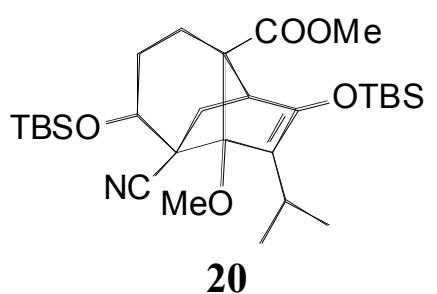

20 warmed to RT and then heated up to $60^{\circ} \mathrm{C}$ for $12 \mathrm{~h}$. It was diluted with EtOAc $(15 \mathrm{~mL})$ and neutralized with aq. sat'd. $\mathrm{NaHCO}_{3}(5 \mathrm{~mL})$. The organic phase was separated and washed with brine $(5 \mathrm{~mL})$, dried $\left(\mathrm{Na}_{2} \mathrm{SO}_{4}\right)$ and concentrated. Chromatography of the residue (30:70 methylene chloride /hexanes) gave $23 \mathrm{mg}(45 \%)$ of a mixture of diastereomers of $\mathbf{2 0}$ as a colorless oil. ${ }^{1} \mathbf{H}$ (single diastereoisomer): $4.39(\mathrm{~m}, 1 \mathrm{H})$;

$3.74(\mathrm{~s}, 3 \mathrm{H}) ; 3.62(\mathrm{~s}, 3 \mathrm{H}) ; 2.71(\mathrm{~d}, J=4.3,1 \mathrm{H}) ; 2.51$ (sept, $J=6.9,1 \mathrm{H}) ; 2.46(\mathrm{dd}, J=13.1,4.4$, $1 \mathrm{H}) ; 2.04-1.87(\mathrm{~m}, 2 \mathrm{H}) ; 1.73-1.54(\mathrm{~m}, 2 \mathrm{H}) ; 1.48(\mathrm{~d}, J=13.1,1 \mathrm{H}) ; 1.32(\mathrm{~d}, J=6.8,3 \mathrm{H}) ; 1.15(\mathrm{~d}$, $J=6.8,3 \mathrm{H}) ; 0.96(\mathrm{~s}, 9 \mathrm{H}) ; 0.91(\mathrm{~s}, 9 \mathrm{H}) ; 0.22(\mathrm{~s}, 3 \mathrm{H}) ; 0.21(\mathrm{~s}, 3 \mathrm{H}) ; 0.19$ (s, 3H); $0.11(\mathrm{~s}, 3 \mathrm{H})$. ${ }^{13} \mathbf{C}$ (single diastereoisomer): $174.7 ; 158.7 ; 124.6 ; 122.9 ; 95.6 ; 70.1 ; 67.4 ; 57.4 ; 52.8 ; 52.6$; $49.1 ; 33.7 ; 28.1 ; 26.7 ; 26.5 ; 25.7 ; 25.5 ; 23.5 ; 21.4 ; 19.0 ; 18.9 ;-2.2 ;-2.7 ;-3.2 ;-3.6$. IR: 2315, 1730. HRMS: calc. for $\mathrm{C}_{29} \mathrm{H}_{51} \mathrm{NO}_{5} \mathrm{Si}_{2}[\mathrm{M}+\mathrm{Na}]^{+}$572.3306; found 572.3305.

Compound 21. Neat TIPS-OTf $(190 \mu \mathrm{L}, 710 \mu \mathrm{mol})$ was added to a cold $\left(0^{\circ} \mathrm{C}\right) \mathrm{CH}_{2} \mathrm{Cl}_{2}(1.3$ $\mathrm{mL}$ ) solution of 16 (104 mg, $320 \mu \mathrm{mol} ; 1: 1$ mixture of diastereomers) and Hünig base (140

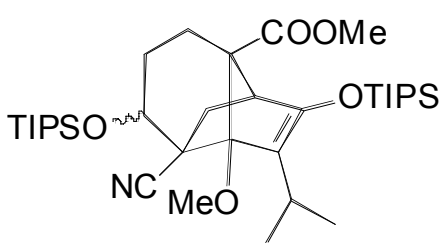

21 $\mu \mathrm{L}, 810 \mu \mathrm{mol})$. The solution was warmed to RT and stirred for $12 \mathrm{~h}$, then it was diluted with a 3:1 mixture of pentane $/ \mathrm{CH}_{2} \mathrm{Cl}_{2}$ $(10 \mathrm{~mL})$, resulting in precipitation of a white solid which was filtered off. The filtrate was washed with aq. sat'd. $\mathrm{NaHCO}_{3}(3$ $\mathrm{mL})$, dried $\left(\mathrm{Na}_{2} \mathrm{SO}_{4}\right)$ and concentrated. Chromatography of the residue (5:95 EtOAc/hexanes) gave $123 \mathrm{mg}(61 \%)$ of a nearly 1:1 mixture of diastereomers of $\mathbf{2 1}$ as an colorless oil. ${ }^{\mathbf{1}} \mathbf{H}: 4.57$

$\left(\mathrm{dd}_{\text {app. }}, J=8.6,6.1,1 \mathrm{H}\right) ; 4.41(\mathrm{t}, J=8.3,1 \mathrm{H}) ; 3.91(\mathrm{~s}, 3 \mathrm{H}) ; 3.77(\mathrm{~s}, 3 \mathrm{H}) ; 3.64(\mathrm{~s}, 3 \mathrm{H}) ; 3.59$ (s, $3 \mathrm{H}) ; 2.75-2.65(\mathrm{~m}, 2 \mathrm{H}) ; 2.58(\mathrm{~m}, 2 \mathrm{H}) ; 2.49-2.42(\mathrm{~m}, 2 \mathrm{H}) ; 2.16(\mathrm{~d}, J=12.9,2 \mathrm{H}) ; 2.05-1.80$ $(\mathrm{m}, 6 \mathrm{H}) ; 1.75-1.40(\mathrm{~m}, 2 \mathrm{H}) ; 1.34(\mathrm{~d}, J=6.7,12 \mathrm{H}) ; 1.23-1.00(\mathrm{~m}, 84 \mathrm{H}) .{ }^{13} \mathbf{C}: 173.8 ; 156.6$; $154.4 ; 124.2 ; 123.9 ; 123.8 ; 122.9 ; 94.8 ; 94.2 ; 75.9 ; 69.8 ; 66.6 ; 66.1 ; 56.8 ; 56.5 ; 52.1 ; 51.9$; $49.9 ; 49.2 ; 48.8 ; 42.5 ; 33.4 ; 27.8 ; 27.7 ; 26.5 ; 25.5 ; 25.1 ; 22.7 ; 21.3 ; 20.6 ; 18.3 ; 13.5 ; 12.9$. IR: 2324, 1745, 1645. HRCIMS: Calc. for $\mathrm{C}_{35} \mathrm{H}_{64} \mathrm{NO}_{5} \mathrm{Si}_{2}[\mathrm{M}+\mathrm{H}]^{+}$634.4323; found 634.4322 .

Ketoalcohol 22. Pyridine-HF complex $(70 \% \mathrm{HF}, 2 \mathrm{~mL})$ was added to a cold $\left(0{ }^{\circ} \mathrm{C}\right)$ solution of $19(206 \mathrm{mg}, 380 \mu \mathrm{mol})$ in $\mathrm{MeCN}(2 \mathrm{~mL})$. The mixture was stirred for $1 \mathrm{~h}$, during which

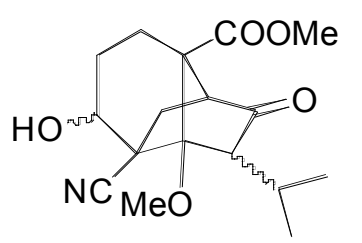

22 time it was allowed to warm to RT, then it was diluted with EtOAc $(20 \mathrm{~mL})$ and neutralized with aq. sat'd. $\mathrm{NaHCO}_{3}(5 \mathrm{~mL})$. The organic phase was separated and washed with brine $(5 \mathrm{~mL})$, dried $\left(\mathrm{Na}_{2} \mathrm{SO}_{4}\right)$ and concentrated to afford $120 \mathrm{mg}(100 \%)$ of a mixture of diastereomers of $\mathbf{2 2}$ as an oil. ${ }^{1} \mathbf{H} 4.48(\operatorname{app} \mathrm{dd}, J=10.5,6.2,1 \mathrm{H})$; $4.00(\mathrm{~m}, 1 \mathrm{H}) ; 3.71(\mathrm{~s}, 3 \mathrm{H}) ; 3.68(\mathrm{~s}, 3 \mathrm{H}) ; 3.58(\mathrm{~s}, 3 \mathrm{H}) ; 3.47(\mathrm{~s}, 3 \mathrm{H})$; $2.82(\mathrm{~d}, J=6.0,1 \mathrm{H}) ; 2.76(\mathrm{~d}, J=6.2,1 \mathrm{H}) ; 2.70(\mathrm{~d}, J=10.0,1.5 \mathrm{H})$;

$2.68-2.38(\mathrm{~m}, 4.5 \mathrm{H}) ; 2.18-1.80(\mathrm{~m}, 8 \mathrm{H}) ; 1.60(\mathrm{~d}, J=15.0,2 \mathrm{H}) ; 1.31(\mathrm{~d}, J=6.4,6 \mathrm{H}) ; 1.24$ (app dd, $J=6.8,4.5,6 \mathrm{H}) .{ }^{13} \mathrm{C}: 206.9,205.7 ; 173.6,173.2 ; 121.1 ; 91.4 ; 90.5 ; 75.0 ; 67.7 ; 57.3$; $57.0 ; 54.3 ; 54.1 ; 53.6 ; 53.3 ; 53.0 ; 52.8 ; 49.2 ; 44.7 ; 29.8 ; 27.4 ; 27.3 ; 25,9 ; 25,6 ; 24.4 ; 24.4$; 23.5; 22.5; 22.4; 21.6. IR: 3455, 2246, 1728. HRCIMS: Calc. for $\mathrm{C}_{17} \mathrm{H}_{24} \mathrm{NO}_{5}[\mathrm{M}+\mathrm{H}]^{+}$ 322.1654 ; found 322.1652 . 
Diketone 23. Neat DMSO $(70 \mu \mathrm{L}, 900 \mu \mathrm{mol})$ was added to a cold $\left(-78{ }^{\circ} \mathrm{C}\right)$ solution of $(\mathrm{COCl})_{2}(40 \mu \mathrm{L}, 430 \mu \mathrm{mol})$ in $\mathrm{CH}_{2} \mathrm{Cl}_{2}(500 \mu \mathrm{L}$; CAUTION: vigorous reaction, formation of

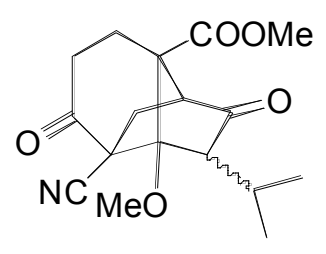

23 highly toxic $\mathrm{CO}$ ). The mixture was stirred at $-78{ }^{\circ} \mathrm{C}$ for $15 \mathrm{~min}$, then a solution of $22(60 \mathrm{mg}, 190 \mu \mathrm{mol})$ in $\mathrm{CH}_{2} \mathrm{Cl}_{2}(600 \mu \mathrm{L})$ was added dropwise and the mixture was stirred at $-78{ }^{\circ} \mathrm{C}$ for 30 min. Neat $\mathrm{Et}_{3} \mathrm{~N}$ $(210 \mu \mathrm{L}, 1500 \mu \mathrm{mol})$ was then slowly injected and the mixture was stirred at $-78{ }^{\circ} \mathrm{C}$ for another $30 \mathrm{~min}$, then it was allowed to warm to RT. The mixture was diluted with half-saturated aq. $\mathrm{NH}_{4} \mathrm{Cl}$ solution (2 $\mathrm{mL})$ and more $\mathrm{CH}_{2} \mathrm{Cl}_{2}(10 \mathrm{~mL})$. The organic phase was separated,

dried $\left(\mathrm{Na}_{2} \mathrm{SO}_{4}\right)$ and concentrated. The residue was chromatographed (30:70 EtOAc/hexanes) to furnish $40 \mathrm{mg}(67 \%)$ of a nearly $1: 1$ mixture of diastereomers of $23 .{ }^{1} \mathbf{H}: 3.76(\mathrm{~s}, 3 \mathrm{H}) ; 3.50$ $(\mathrm{s}, 3 \mathrm{H}) ; 2.92(\mathrm{~d}, J=6.0,1 \mathrm{H}) ; 2.83-2.73(\mathrm{~m}, 4 \mathrm{H}) ; 2.65-2.53(\mathrm{~m}, 1 \mathrm{H}) ; 2.50(\mathrm{dd}, J=15.2,5.8$, $1 \mathrm{H}) ; 2.25-2.10(\mathrm{~m}, 2 \mathrm{H}) ; 1.31(\mathrm{~d}, J=6.6,3 \mathrm{H}) ; 1.21(\mathrm{~d}, J=6.7,3 \mathrm{H}) .{ }^{13} \mathbf{C}: 206.8 ; 199.1 ; 172.8$; $117.0 ; 94.4 ; 56.9 ; 56.0 ; 55.8 ; 55.3 ; 54.3 ; 53.3 ; 31.9 ; 30.3 ; 27.0 ; 23.5 ; 23.1 ; 22.8$. IR: 2954, 2872, 2238, 1750, 1716, 1621, 1435. HRCIMS: Calc. for $\mathrm{C}_{17} \mathrm{H}_{22} \mathrm{NO}_{5}[\mathrm{M}+\mathrm{H}]^{+} 320.1498$; found 320.1499 .

Ketone 24. A solution of 16 (800 mg, $2.5 \mathrm{mmol})$, imidazole (253 mg, $3.7 \mathrm{mmol})$, DMAP (30 $\mathrm{mg}, 245 \mu \mathrm{mol})$ and TBSCl $(747 \mathrm{mg}, 5 \mathrm{mmol})$ in dry DMF $(2 \mathrm{~mL})$ was stirred at $60{ }^{\circ} \mathrm{C}$ for

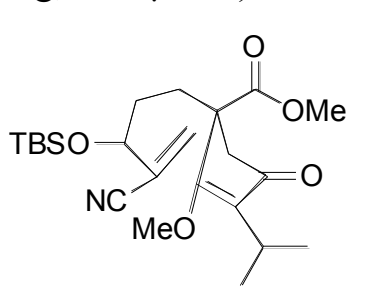

24

$11 \mathrm{~h}$, then it was cooled to RT, diluted with sat'd. aq, $\mathrm{NH}_{4} \mathrm{Cl}(20 \mathrm{~mL})$ and extracted with EtOAc $(3 \times 10 \mathrm{~mL})$. The combined extracts were washed with brine $(15 \mathrm{~mL})$, dried $\left(\mathrm{MgSO}_{4}\right)$ and concentrated. Chromatography of the residue (gradient 0 --> $25 \%$ EtOAc / hehanes) gave $758 \mathrm{mg}(70 \%)$ of a nearly $60: 40$ mixture of diastereomers of $\mathbf{2 4}$ as a light yellow oil. ${ }^{1} \mathbf{H}$ : $5.98-5.89(\mathrm{~m}, 2 \mathrm{H}) ; 4.30-4.20(\mathrm{~m}, 1 \mathrm{H})$; 3.98$3.93(\mathrm{~m}, 3 \mathrm{H}) ; 3.72(\mathrm{~s}, 3 \mathrm{H}) ; 3.01-2.91(\mathrm{~m}, 1 \mathrm{H}) ; 2.66(\mathrm{dd}, J=17.5,4.2$,

$1 \mathrm{H}) ; 2.26(\mathrm{dd}, J=17.5,6.6,1 \mathrm{H}) ; 1.95-1.82(\mathrm{~m}, 2 \mathrm{H}) ; 1.56-1.43(\mathrm{~m}, 2 \mathrm{H}) ; 1.22(\mathrm{dd}, J=6.9,4.3$, $6 \mathrm{H}) ; 0.90(\mathrm{~s}, 9 \mathrm{H}) ; 0.06-0.04(\mathrm{~m}, 6 \mathrm{H}) .{ }^{13} \mathrm{C}: 202.5 ; 179.8,179.7 ; 173.5 ; 129.6 ; 126.6 ; 126.5$; $126.4 ; 116.8 ; 99.5 ; 72.0 ; 71.8 ; 59.2 ; 59.1 ; 52.6 ; 52.0 ; 45.0 ; 44.9 ; 30.5 ; 30.3 ; 28.0 ; 27.6 ; 25.5$; $24.1 ; 24.0 ; 20.3 ; 19.97 ; 19.95 ; 17.95 ;-4.96 ;-4.98 ;-5.16 ;-5.18$. IR: 2223, 1736, 1619. HRESIMS: calc. for $\mathrm{C}_{23} \mathrm{H}_{38} \mathrm{NO}_{5} \mathrm{Si}[\mathrm{M}+\mathrm{H}]^{+} 436.2516$; found 436.2519.

Cyanoenone 25. Commercial $\mathrm{Et}_{2} \mathrm{AlCN}$ solution (1.0 $\mathrm{M}$ in toluene, $3.3 \mathrm{~mL}, 3.3 \mathrm{mmol}$ ) was added at RT to a stirred solution of $\mathbf{2 4}(729 \mathrm{mg}, 1.7 \mathrm{mmol}, 60: 40$ mixture of diastereomers) in

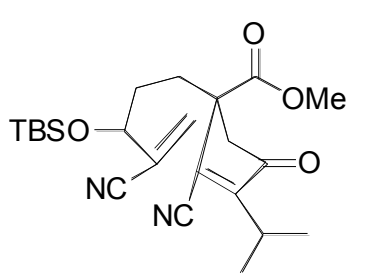

25 dry benzene $(15 \mathrm{~mL})$. The mixture was stirred at RT for $1.5 \mathrm{~h}$, then it was quenched with $1 \mathrm{M} \mathrm{NaOH}(4 \mathrm{~mL})$ and concentrated. The residue was taken up with aq. sat'd $\mathrm{NaHCO}_{3}(20 \mathrm{~mL})$ and with EtOAc $(20$ $\mathrm{mL})$. The organic phase was recovered and the aqueous phase was further extracted with EtOAc $(3 \times 10 \mathrm{~mL})$. The combined extracts were washed with brine $(15 \mathrm{~mL})$, dried $\left(\mathrm{MgSO}_{4}\right)$, and concentrated.

The residue was chromatographed (25:75 EtOAc/hexanes) to give $508 \mathrm{mg}(70 \%)$ of a nearly $60: 40$ mixture of diastereomers of $\mathbf{2 5}$ as a light yellow oil. ${ }^{1} \mathbf{H}$ : 6.05-5.95 (m, 2H); 4.35-4.25 (m, 1H); 3.85-3.77 (m, 3H); $3.07(\mathrm{dd}, J=19.0,3.0,1 \mathrm{H})$; 3.01$2.95(\mathrm{~m}, 1 \mathrm{H}) ; 2.37(\mathrm{dd}, J=19.0,3.0,1 \mathrm{H}) ; 2.25-2.15(\mathrm{~m}, 1 \mathrm{H}) ; 1.85-1.45(\mathrm{~m}, 3 \mathrm{H}) ; 1.30-1.23$ $(\mathrm{m}, 6 \mathrm{H}) ; 0.95-0.85(\mathrm{~m}, 9 \mathrm{H}) ; 0.12-0.05(\mathrm{~m}, 6 \mathrm{H}) .{ }^{13} \mathrm{C}: 203.1 ; 171.6 ; 171.5 ; 161.8 ; 161.7 ; 136.0$; $135.9 ; 130.5 ; 126.3 ; 126.1 ; 117.0 ; 116.9 ; 113.8 ; 113.7 ; 71.9 ; 71.7 ; 53.7 ; 53.6 ; 43.8 ; 43.6$; $31.5 ; 31.3 ; 31.0 ; 30.6 ; 26.7 ; 25.9 ; 25.8 ; 20.2 ; 20.1 ;-4.60 ;-4.8$. IR: 2225, 1726. HRESIMS: calc. for $\mathrm{C}_{23} \mathrm{H}_{34} \mathrm{~N}_{2} \mathrm{O}_{4} \mathrm{Si}[\mathrm{M}+\mathrm{Na}]^{+} 453.2183$; found. 453.2186 . 
Cyanoalcohol 26. Solid $\mathrm{NaBH}_{4}(4 \mathrm{mg})$ was added to a cold $\left(0{ }^{\circ} \mathrm{C}\right)$ solution of $25(40 \mathrm{mg}, 90$ $\mu \mathrm{mol})$ and $\mathrm{CeCl}_{3} \cdot 7 \mathrm{H}_{2} \mathrm{O}(22 \mathrm{mg}, 59 \mu \mathrm{mol})$ in $\mathrm{MeOH}(1 \mathrm{~mL})$, and the mixture was stirred for 15

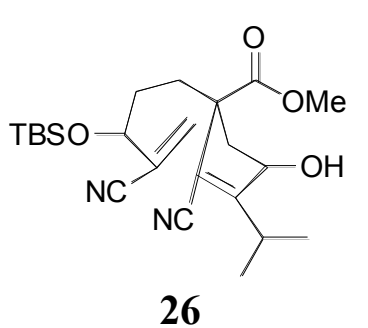
min. The reaction was quenched with aq. sat'd $\mathrm{NH}_{4} \mathrm{Cl}(5 \mathrm{~mL})$ and the mixture was concentrated. The residue was partitioned between EtOAc $(10 \mathrm{~mL})$ and more aq. sat'd. $\mathrm{NH}_{4} \mathrm{Cl}(10 \mathrm{~mL})$. The organic phase was recovered and the aqueous phase was further extracted with EtOAc $(3 \times 10 \mathrm{~mL})$. The combined extracts were washed with brine $(15 \mathrm{~mL})$, dried $\left(\mathrm{MgSO}_{4}\right)$ and concentrated. Chromatography of the residue (25:75 EtOAc/hexanes) gave $20 \mathrm{mg}(51 \%)$ of 26, a mixture of diastereomers, as a light yellow oil. ${ }^{1} \mathbf{H}$ : $6.02-5.91(\mathrm{~m}, 2 \mathrm{H}) ; 5.08-4.95(\mathrm{~m}, 1 \mathrm{H})$; 4.33-4.20 (m, $1 \mathrm{H})$; 3.84-3.68 (m, 3H); 3.01-2.84 (m, 2.2H); 2.59-2.48 (m, 0.4H); 2.29-1.76 (m, 3H); 1.76$1.47(\mathrm{~m}, 1.4 \mathrm{H}) ; 1.40-1.13(\mathrm{~m}, 6 \mathrm{H}) ; 0.97-0.77(\mathrm{~m}, 9 \mathrm{H}) ; 0.23-0.01(\mathrm{~m}, 6 \mathrm{H})$. IR: 3473,2221 , 1734. HRESIMS: calc. for $\mathrm{C}_{23} \mathrm{H}_{36} \mathrm{~N}_{2} \mathrm{O}_{4} \mathrm{Si}[\mathrm{M}+\mathrm{Na}]^{+}$455.2343; found 455.2342.

Diene 27. A solution of $26(19 \mathrm{mg}, 44 \mu \mathrm{mol})$ and Burgess reagent $(21 \mathrm{mg}, 88 \mu \mathrm{mol})$ in dry benzene $(0.5 \mathrm{~mL})$ was stirred at $60{ }^{\circ} \mathrm{C}$ for $15 \mathrm{~h}$, then it was cooled (RT) and concentrated. The

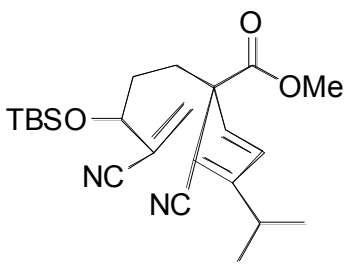

27 residue was partitioned between EtOAc $(10 \mathrm{~mL})$ and aq. sat'd $\mathrm{NaHCO}_{3}(10 \mathrm{~mL})$, the organic phase was recovered and the aqueous phase was further extracted with EtOAc $(3 \times 10 \mathrm{~mL})$. The combined extracts were washed with brine $(15 \mathrm{~mL})$, dried $\left(\mathrm{MgSO}_{4}\right)$ and concentrated. Chromatography of the residue (25:75 EtOAc/hexanes) gave $10 \mathrm{mg}(54 \%)$ of a nearly $70: 30$ mixture of diastereomers of 27 as a light yellow oil. ${ }^{\mathbf{1}} \mathbf{H}$ : $6.60-6.44(\mathrm{~m}, 1 \mathrm{H}) ; 6.03-5.91(\mathrm{~m}, 3 \mathrm{H}) ; 4.33-$

$4.16(\mathrm{~m}, 1 \mathrm{H}) ; 3.83-3.62(\mathrm{~m}, 3 \mathrm{H}) ; 3.13-3.00(\mathrm{~m}, 1 \mathrm{H}) ; 3.00-2.85(\mathrm{~m}, 1 \mathrm{H}) ; 2.37-1.87(\mathrm{~m}, 3 \mathrm{H})$; 1.37-1.10 (m, 6H); 0.97-0.77 (m, 9H); 0.14-0.01 (m, 6H). IR: 2222, 1739. HRESIMS: calc. for $\mathrm{C}_{23} \mathrm{H}_{34} \mathrm{~N}_{2} \mathrm{O}_{4} \mathrm{Si}[\mathrm{M}+\mathrm{Na}]^{+}$437.2233; found 437.2236.

Compound 29. A cold $\left(-78{ }^{\circ} \mathrm{C}\right)$ solution of $25(1.00 \mathrm{~g}, 2.32 \mathrm{mmol})$ in dry THF $(15 \mathrm{~mL})$, containing $95 \% \mathrm{NaH}(84 \mathrm{mg}, 3.5 \mathrm{mmol})$ was stirred for $1.3 \mathrm{~h}$, then it was carefully quenched

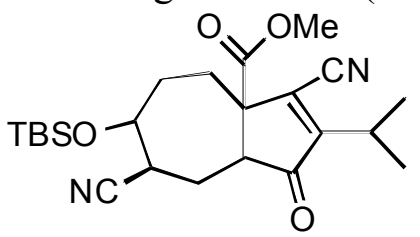

29 with aq. sat'd. $\mathrm{NH}_{4} \mathrm{Cl}(5 \mathrm{~mL}$; CAUTION: evolution of flammable $\mathrm{H}_{2}$ gas) and concentrated. The residue was partitioned between EtOAc $(30 \mathrm{~mL})$ and aq. sat'd $\mathrm{NH}_{4} \mathrm{Cl}(30 \mathrm{~mL})$. The organic phase was recovered and the aqueous phase was further extracted with EtOAc $(3 \times 20 \mathrm{~mL})$. The combined extracts were washed with brine $(15 \mathrm{~mL})$, dried $\left(\mathrm{MgSO}_{4}\right)$ and concentrated. Chromatography of the residue (10:90 EtOAc/hexanes) gave 298mg (29\%) of a mixture of diastereomers of 29 as a light yellow oil. ${ }^{1} \mathbf{H}$ : 4.47-4.42 (m, 0.3H); 4.42-4.34 (m, 0.2H); 4.32-4.21 (m, 0.5H); 3.88$3.81(\mathrm{~s}, 1.3 \mathrm{H}) ; 3.81-3.74(\mathrm{~m}, 1.7 \mathrm{H}) ; 3.37-3.29(\mathrm{~m}, 0.45 \mathrm{H}) ; 3.05-2.90(\mathrm{~m}, 1 \mathrm{H}) ; 2.85-2.65(\mathrm{~m}$, $1 \mathrm{H}) ; 2.64-2.29(\mathrm{~m}, 1.85 \mathrm{H}) ; 2.29-1.90(\mathrm{~m}, 2.95 \mathrm{H}) ; 1.85-1.44(\mathrm{~m}, 1.75 \mathrm{H}) ; 1.42-1.34(\mathrm{~d}, J=6.3$, $0.6 \mathrm{H}) ; 1.34-1.22(\mathrm{~m}, 4.2 \mathrm{H}) ; 1.13-1.03(\mathrm{~d}, J=6.8,1.2 \mathrm{H}) ; 0.99-0.82(\mathrm{~m}, 9 \mathrm{H}) ; 0.25-0.08(\mathrm{~m}, 6 \mathrm{H})$. ${ }^{13}$ C: $205.3205 .2 ; 204.4 ; 172.0 ; 171.2 ; 171.0 ; 160.4 ; 136.3 ; 121.0 ; 119.1 ; 116.2 ; 115.0 ; 114.1$; $70.3 ; 69.5 ; 62.0 ; 59.8 ; 59.0 ; 58.2 ; 57.9 ; 53.9 ; 53.7 ; 53.5 ; 52.6 ; 51.9 ; 50.8 ; 47.9 ; 37.3 ; 32.2$; $29.8 ; 29.3 ; 27.9 ; 27.8 ; 27.6 ; 27.4 ; 26.9 ; 26.4 ; 26.1 ; 26.0 ; 25.9 ; 25.8 ; 25.0 ; 24.3 ; 24.1 ; 22.5$; $20.4 ; 20.3 ; 20.0 ; 18.3 ; 18.2 ;-3.93 ;-3.99 ;-4.29 ;-4.52 ;-4.63$. IR: 2260, 1767, 1735. HRESIMS: calc. for $\mathrm{C}_{23} \mathrm{H}_{34} \mathrm{~N}_{2} \mathrm{O}_{4} \mathrm{Si}[\mathrm{M}+\mathrm{Na}]^{+} 453.2185$; found 453.2186.

Silyl enol ether 30. Commercial LHMDS solution (1.0 M in THF, $0.3 \mathrm{~mL}, 0.3 \mathrm{mmol})$ was slowly added to a cold $\left(-78{ }^{\circ} \mathrm{C}\right)$, stirred solution of 25 (133 $\left.\mathrm{mg}, 0.3 \mathrm{mmol}\right), \mathrm{LiCl}(347 \mathrm{mg}, 8.7$ mmol) and TBSCl (924 mg, $6.2 \mathrm{mmol})$ in dry THF $(2 \mathrm{~mL})$ and HMPA $(0.7 \mathrm{~mL}$; CAUTION: cancer suspect agent). The mixture was stirred at $-78^{\circ} \mathrm{C}$ for $30 \mathrm{~min}$, then it was heated to 50 


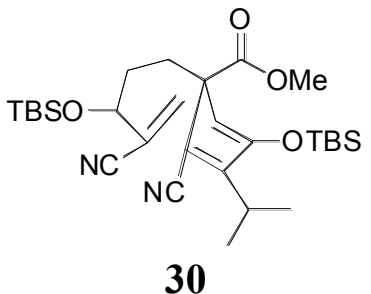

30

${ }^{\circ} \mathrm{C}$.An additional 5 portions of LHMDS (1.0 M in THF, each portion $0.3 \mathrm{~mL}, 0.3 \mathrm{mmol}$ ) were added at regular intervals over $8 \mathrm{~h}$. Finally, the mixture was cooled, carefully quenched with aq. sat'd. $\mathrm{NH}_{4} \mathrm{Cl}(2$ $\mathrm{mL}$ ), and concentrated. The residue was partitioned between EtOAc $(20 \mathrm{~mL})$ and aq. sat'd. $\mathrm{CuSO}_{4}(20 \mathrm{~mL})$, the organic phase was recovered and the aqueous phase was extracted with EtOAc $(3 \times 10$ $\mathrm{mL})$. The combined extracts were washed with brine $(15 \mathrm{~mL})$, dried $\left(\mathrm{MgSO}_{4}\right)$ and concentrated. The residue was chromatographed (1:9

EtOAc/hexanes) to give $138 \mathrm{mg}(82 \%)$ of a ca. $1: 1$ mixture of diastereomers of diene $\mathbf{3 0}$ as a light yellow oil. ${ }^{1} \mathbf{H}: 6.00-5.95(\mathrm{~m}, 2 \mathrm{H})$; 5.36-5.30 (m, 1H); 4.30-4.20 (m, 1H); 3.74-3.70 (m, $3 \mathrm{H}) ; 3.09-2.85(\mathrm{~m}, 1 \mathrm{H}) ; 2.26-2.08(\mathrm{~m}, 1 \mathrm{H}) ; 2.02-1.80(\mathrm{~m}, 2 \mathrm{H}) ; 1.72-1.47(\mathrm{~m}, 1 \mathrm{H}) ; 1.34-1.25$ $(\mathrm{m}, 6 \mathrm{H}) ; 1.03-0.84(\mathrm{~m}, 18 \mathrm{H}) ; 0.37-0.02(\mathrm{~m}, 12 \mathrm{H}) .{ }^{13} \mathrm{C}: 172.3 ; 172.2 ; 171.0 ; 170.8 ; 157.4$; $156.5 ; 131.3 ; 128.0 ; 127.9 ; 118.3 ; 116.7 ; 116.6 ; 114.6 ; 114.5 ; 113.4 ; 73.8 ; 73.5 ; 54.6 ; 54.3$; $32.2 ; 31.1 ; 29.6 ; 29.3 ; 27.1 ; 27.0 ; 21.9 ; 21.8 ; 21.6 ; 21.5 ; 21.4 ; 21.3 ; 19.5 ;-3.3 ;-3.4 ;-3.5 ;-3.7$. IR: 2209, 1736. HRESIMS: calc. for $\mathrm{C}_{29} \mathrm{H}_{48} \mathrm{~N}_{2} \mathrm{O}_{4} \mathrm{Si}_{2}[\mathrm{M}+\mathrm{Na}]^{+}$567.3054; found 567.3050.

Cycloadduct 31. A solution of $\mathbf{3 0}(80 \mathrm{mg}, 147 \mu \mathrm{mol})$ in dry toluene $(1 \mathrm{~mL})$ was stirred at 140 ${ }^{\circ} \mathrm{C}$ in a $20 \mathrm{~mL}$ glass pressure vessel for $12 \mathrm{~h}$, then it was cooled to RT and applied to a silica

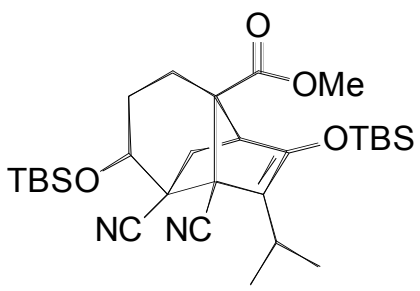

31 silica gel column (10 g). Elution (gradient 0 --> 15\% EtOAc / hexanes) gave $62 \mathrm{mg}(77.5 \%)$ of a nearly $50: 50$ mixture of diastereomers of $\mathbf{3 1}$ as a light yellow oil. ${ }^{\mathbf{1}} \mathbf{H}$ : $4.43-4.32(\mathrm{~m}, 1 \mathrm{H})$; $3.76-3.66(\mathrm{~m}, 3 \mathrm{H}) ; 2.85(\mathrm{~d}, J=4.1,0.5 \mathrm{H}) ; 2.78(\mathrm{~d}, J=4.1,0.5 \mathrm{H})$; $2.65-2.49(\mathrm{~m}, 2 \mathrm{H}) ; 2.26-1.89(\mathrm{~m}, 3 \mathrm{H}) ; 1.81(\mathrm{dd}, J=12.0,4.0,1 \mathrm{H})$; $1.62(\mathrm{~d}, J=12.0,1 \mathrm{H}) ; 1.24(\mathrm{~d}, J=8,3 \mathrm{H}) 1.15(\mathrm{~d}, J=8,3 \mathrm{H}) ; 0.98$ $0.86(\mathrm{~m}, 18 \mathrm{H}) ; 0.21-0.09(\mathrm{~m}, 12 \mathrm{H}) .{ }^{13} \mathrm{C}: 172.1 ; 171.7 ; 158.1$; $157.9 ; 120.7 ; 120.9 ; 119.8 ; 120.5 ; 116.4 ; 116.7 ; 72.9 ; 70.1 ; 67.1$;

$66.8 ; 52.1 ; 52.0 ; 51.3 ; 50.4 ; 50.0 ; 38.2 ; 32.9 ; 29.5 ; 26.7 ; 26.4 ; 25.6 ; 25.3 ; 22.0 ; 22.5 ; 20.4$; $20.3 ; 17.7 ; 17.8 ;-3.7 ;-3.6 ;-4.2 ;-4.5 ;-4.96 ;-4.94$. IR: 2210,1739 . HRESIMS: calc. for $\mathrm{C}_{29} \mathrm{H}_{48} \mathrm{~N}_{2} \mathrm{O}_{4} \mathrm{Si}_{2}[\mathrm{M}+\mathrm{Na}]^{+}$567.3053; found 567.3050.

Tricyclic ketone 33. Commercial HF - pyridine complex (70\% HF, $0.9 \mathrm{~mL}$ ) was added to a cold $\left(0{ }^{\circ} \mathrm{C}\right)$, stirred solution of $\mathbf{3 1}(91 \mathrm{mg}, 167 \mu \mathrm{mol})$ in MeCN $(3 \mathrm{~mL})$. The mixture was

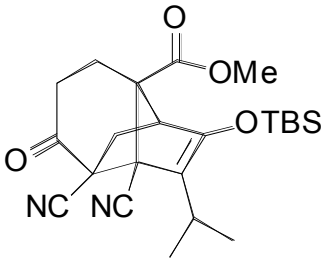

33 stirred for $6 \mathrm{~h}$, during which time it was allowed to warm to RT, and then quenched with aq. sat'd $\mathrm{NaHCO}_{3}(2 \mathrm{~mL})$ and concentrated. The residue was partitioned between EtOAc $(15 \mathrm{~mL})$ and more aq. sat'd $\mathrm{NaHCO}_{3}(20 \mathrm{~mL})$. The organic phase was recovered and the aqueous phase was extracted with more EtOAc $(3 \times 10 \mathrm{ml})$. The combined extracts were washed (brine, $15 \mathrm{~mL})$, dried $\left(\mathrm{MgSO}_{4}\right)$, and concentrated. The crude was carried onto the next step without further purification.

A solution of deprotected alcohol (crude $74 \mathrm{mg}, 172 \mu \mathrm{mol}$ ) and Dess-Martin periodinane (219 $\mathrm{mg}, 516 \mu \mathrm{mol}$ ) in $\mathrm{CH}_{2} \mathrm{Cl}_{2}$ was stirred at $\mathrm{RT}$ for $3 \mathrm{~h}$, then it was concentrated. Chromatography of the residue (gradient 5\% --> 10\% EtOAc / hexanes) gave 33 (58 mg, $79 \%$ over two steps) as a colorless oil. ${ }^{1} \mathbf{H}: 3.78(\mathrm{~s}, 3 \mathrm{H}) ; 3.05(\mathrm{~d}, J=3.9,1 \mathrm{H}) ; 2.90-2.68(\mathrm{~m}, 2 \mathrm{H}) ; 2.62$ (sept, $J=7.0$, $1 \mathrm{H}), 2.47(\mathrm{dd}, J=13.5,3.9,1 \mathrm{H}), 2.29-2.18(\mathrm{~m}, 1 \mathrm{H}), 2.10(\mathrm{~d}, J=3.5,1 \mathrm{H}) ; 2.04-1.90(\mathrm{~m}, 1 \mathrm{H})$; $1.30(\mathrm{~d}, J=6.8,3 \mathrm{H}) ; 1.17(\mathrm{~d}, J=6.8,3 \mathrm{H}) ; 0.96(\mathrm{~s}, 9 \mathrm{H}) ; 0.26(\mathrm{~s}, 3 \mathrm{H}) ; 0.23(\mathrm{~s}, 3 \mathrm{H}) .{ }^{13} \mathrm{C}: 198.8$; $170.9 ; 156.7 ; 120.7 ; 116.3 ; 115.8 ; 66.5 ; 59.6 ; 57.1 ; 52.9 ; 52.7 ; 36.6 ; 31.2 ; 27.2 ; 25.6 ; 23.6$; $22.1 ; 20.8 ;-3.3 ;-3.9$. IR: $2359,1734,1646$. HRESIMS: calc. for $\mathrm{C}_{23} \mathrm{H}_{33} \mathrm{~N}_{2} \mathrm{O}_{4} \mathrm{Si}[\mathrm{M}+\mathrm{H}]^{+}$ 429.2206; found 429.2210. 

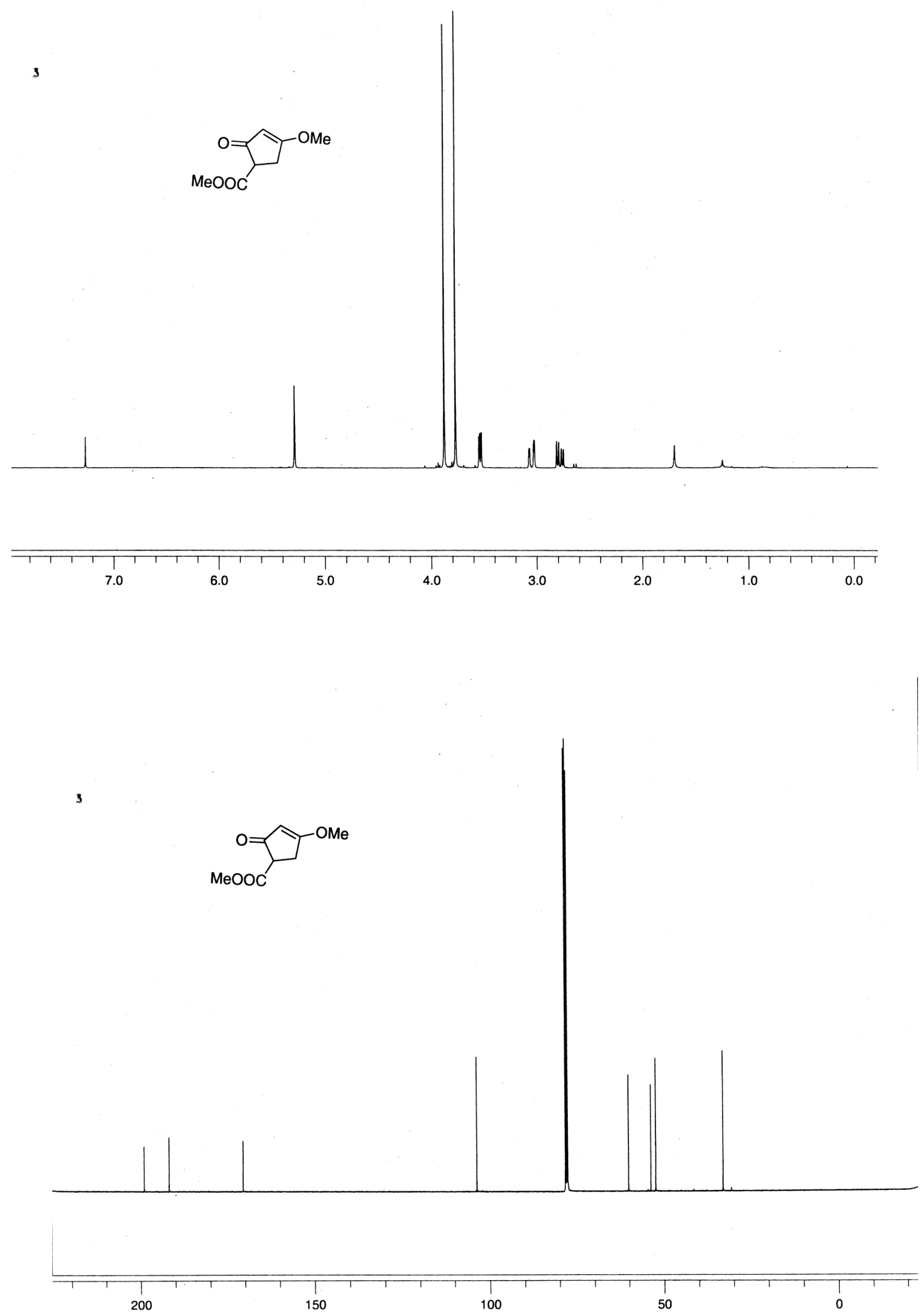

Compound 11 


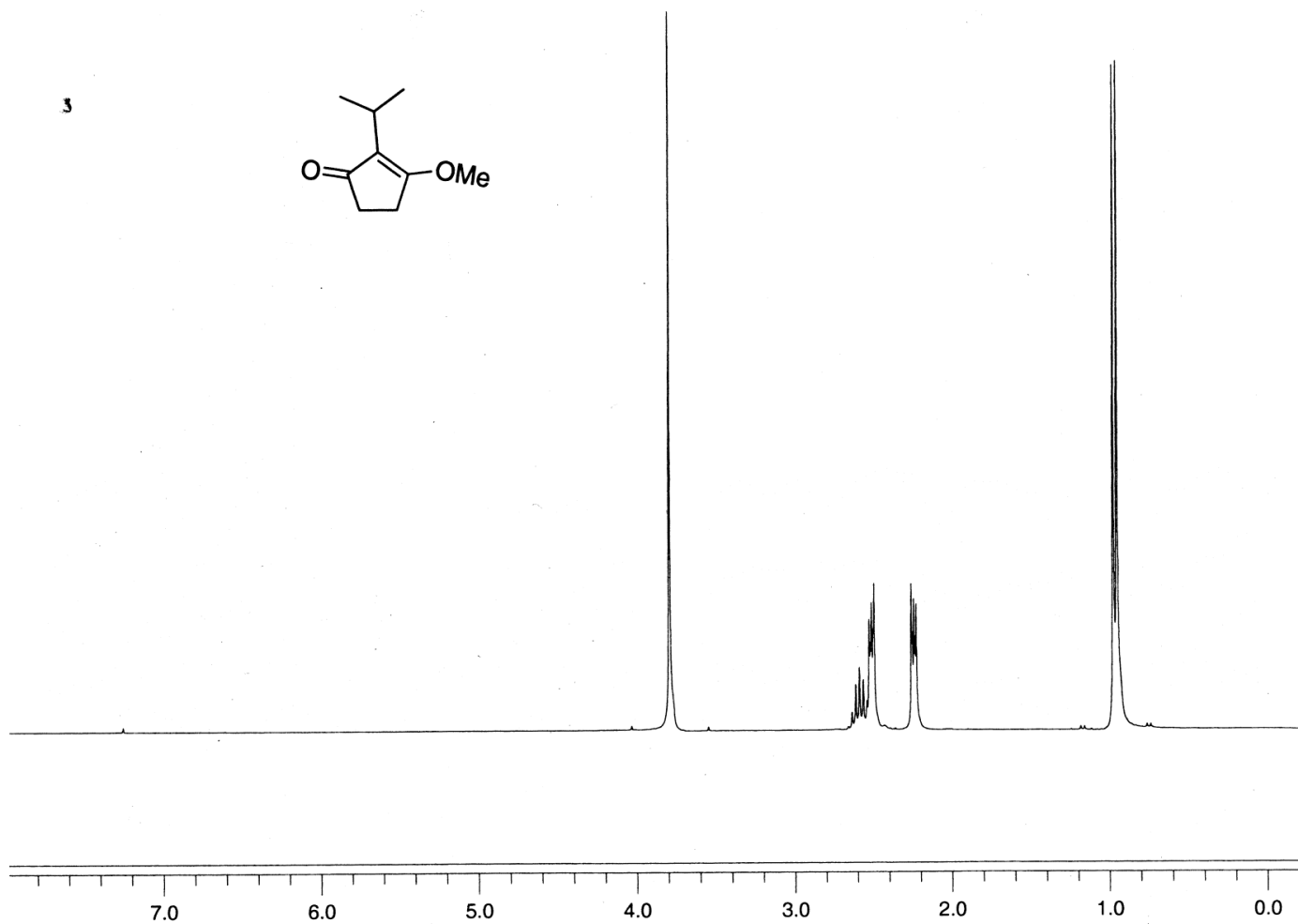

3
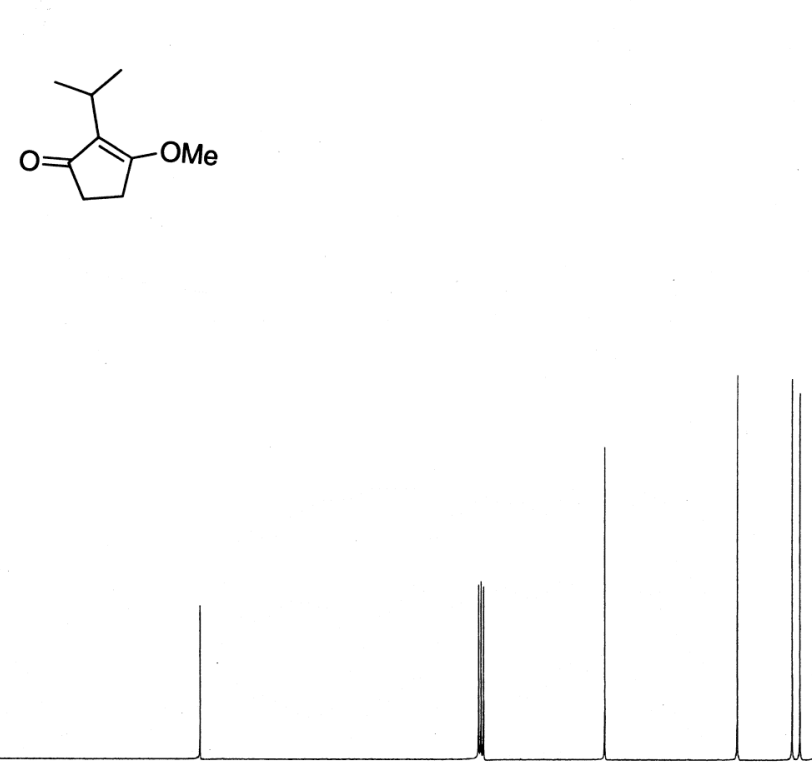

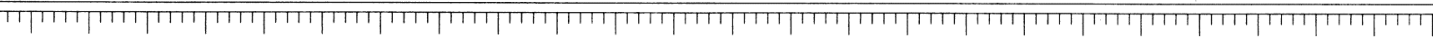
$\begin{array}{llllllllllllllllllllllll}220 & 210 & 200 & 190 & 180 & 170 & 160 & 150 & 140 & 130 & 120 & 110 & 100 & 90 & 80 & 70 & 60 & 50 & 40 & 30 & 20 & 10 & 0 & -10\end{array}$

\section{Compound 10}



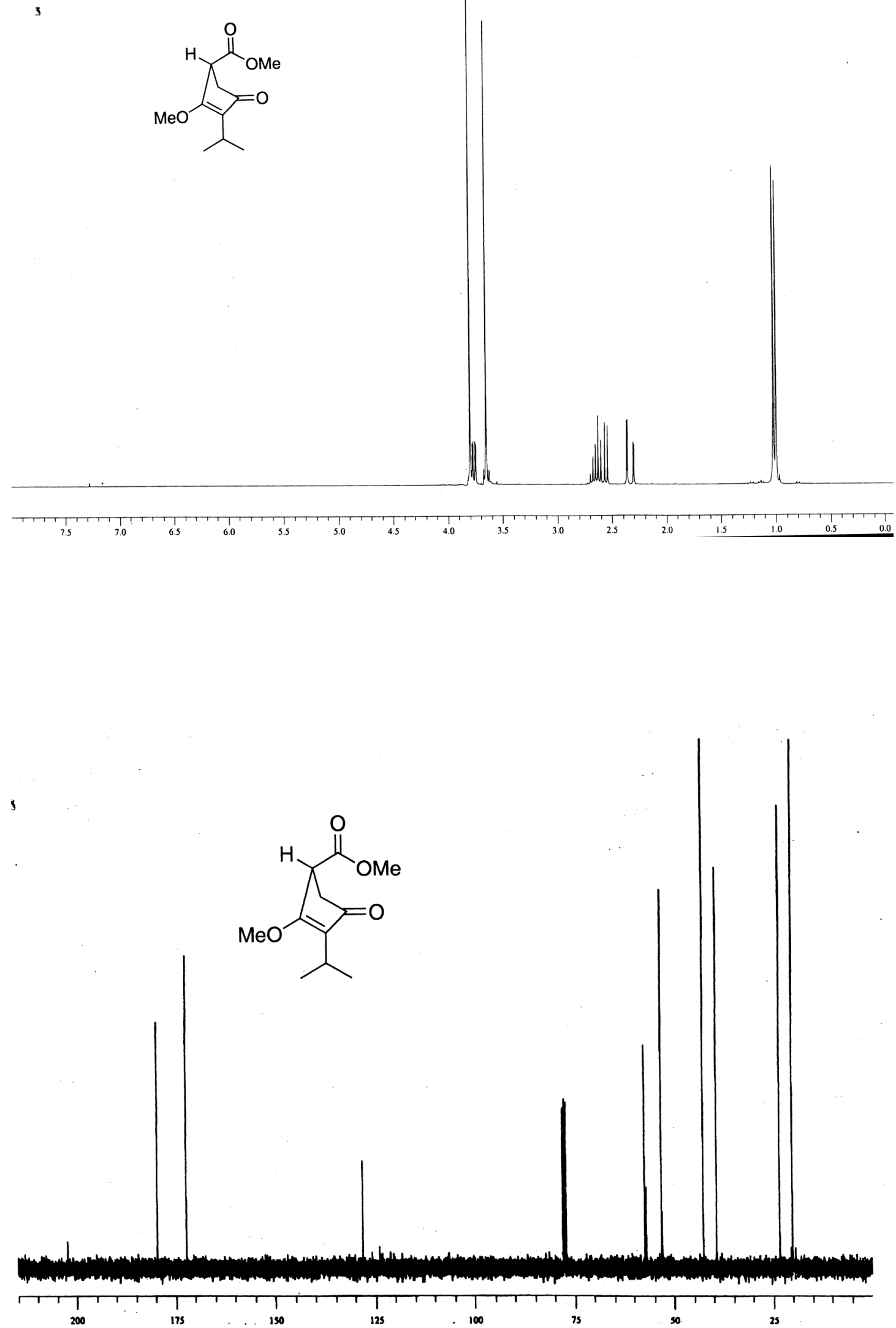

Compound 12 

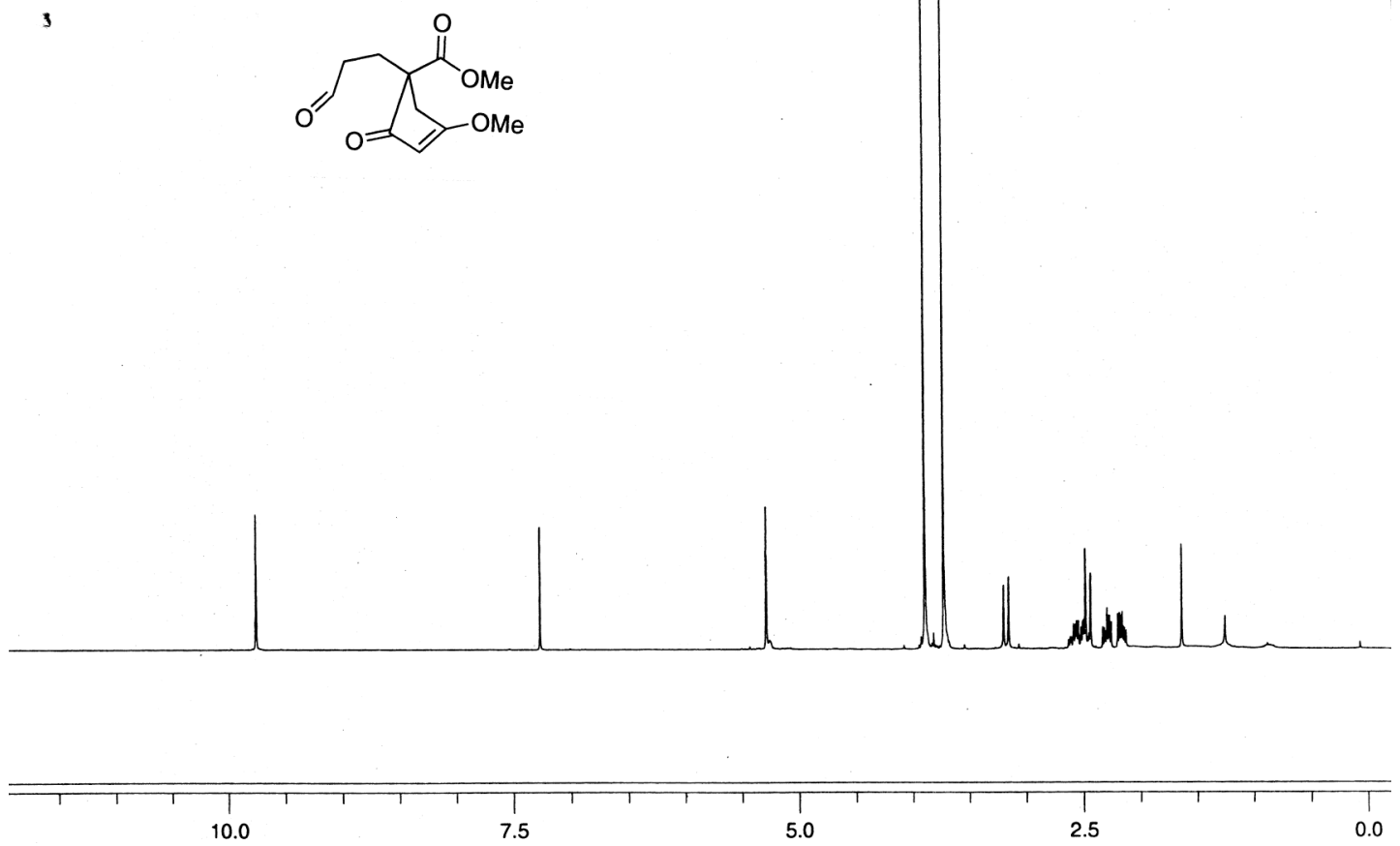

3
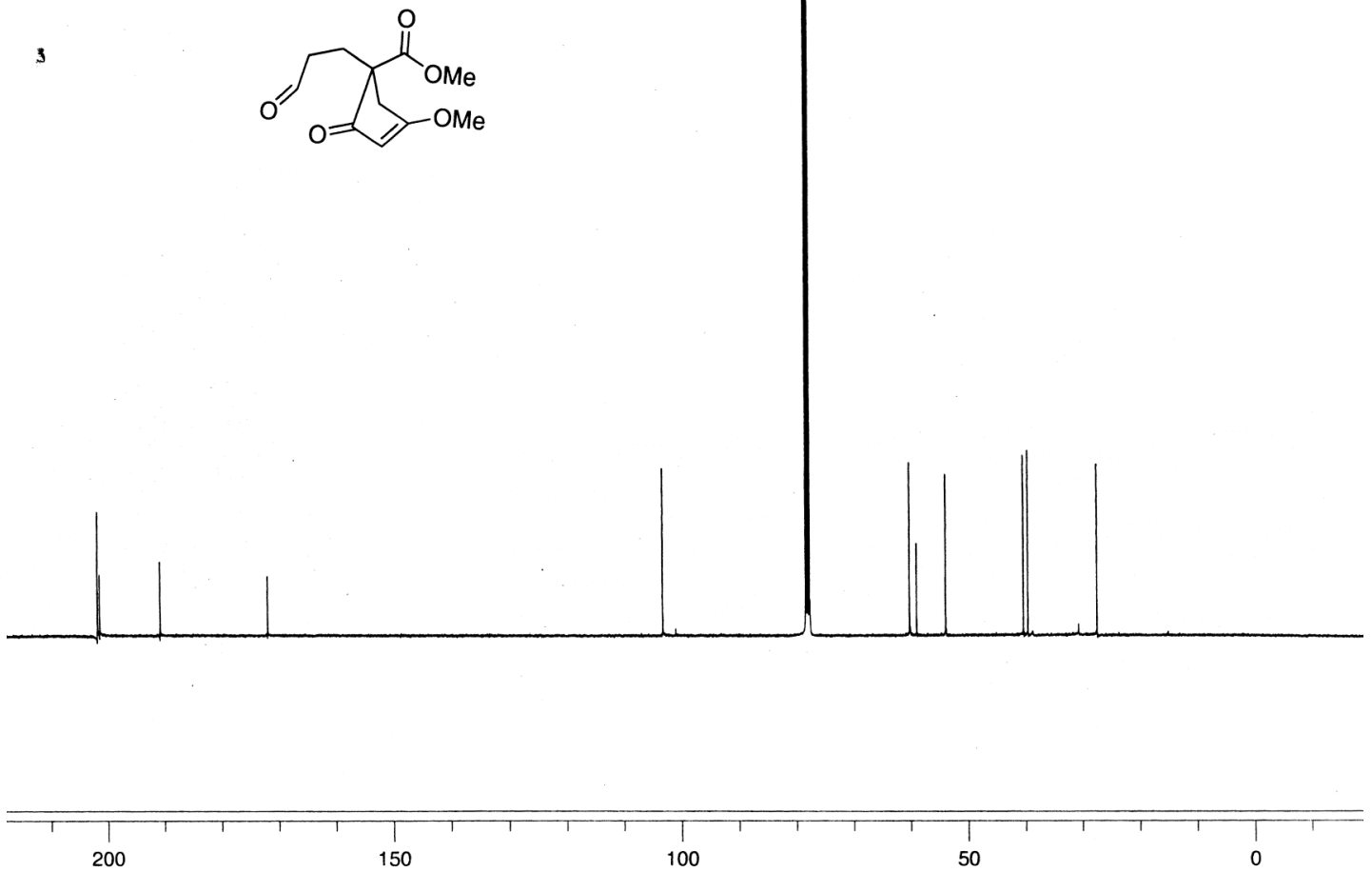

Compound 13 
Ciufolini, M. A., et al.

S 14
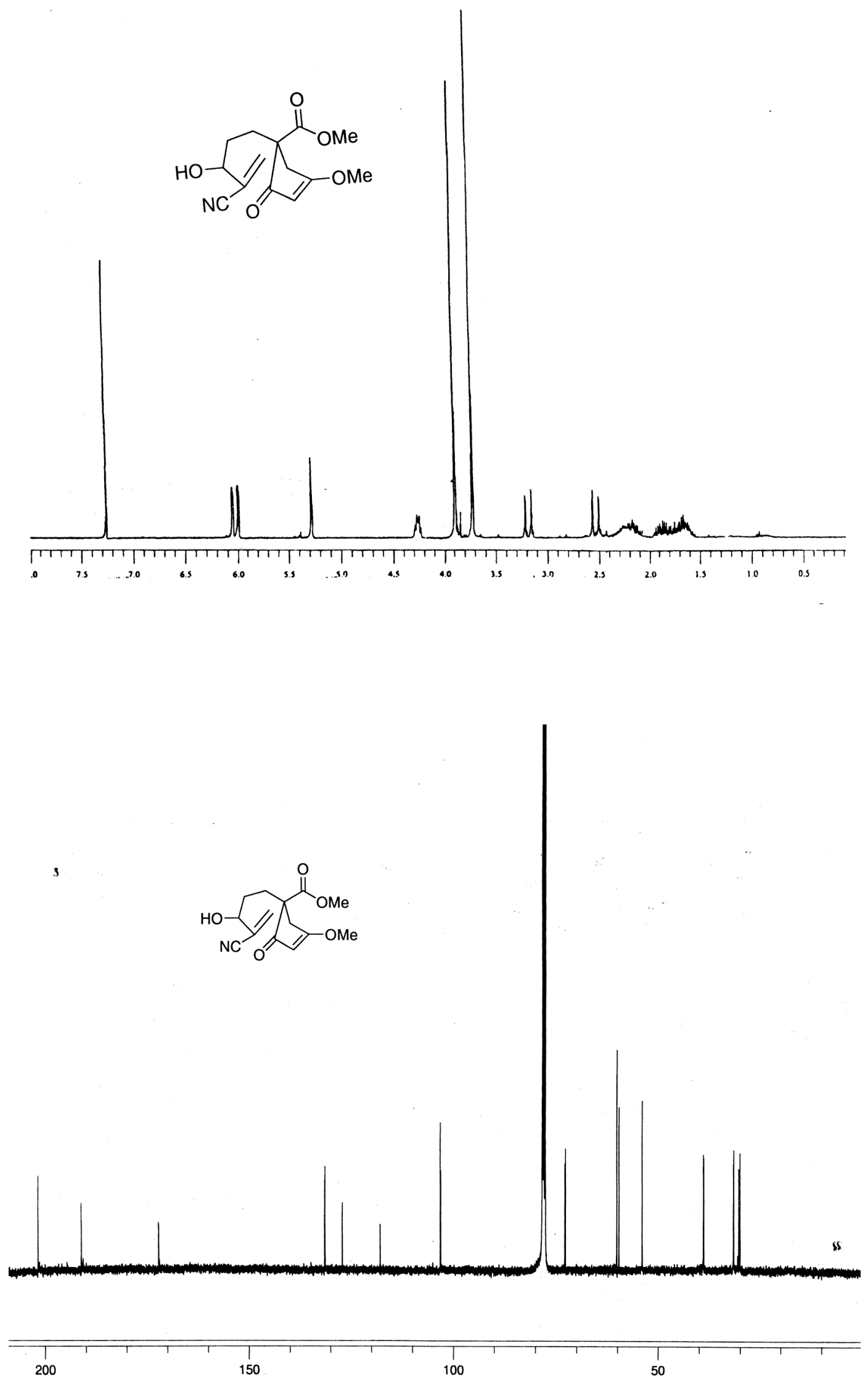

Compound 14 


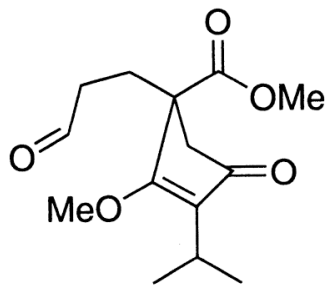

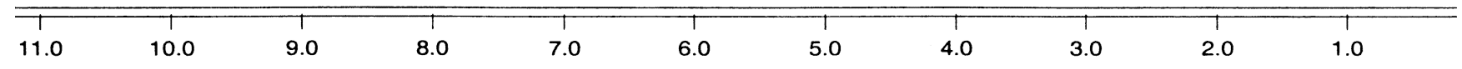

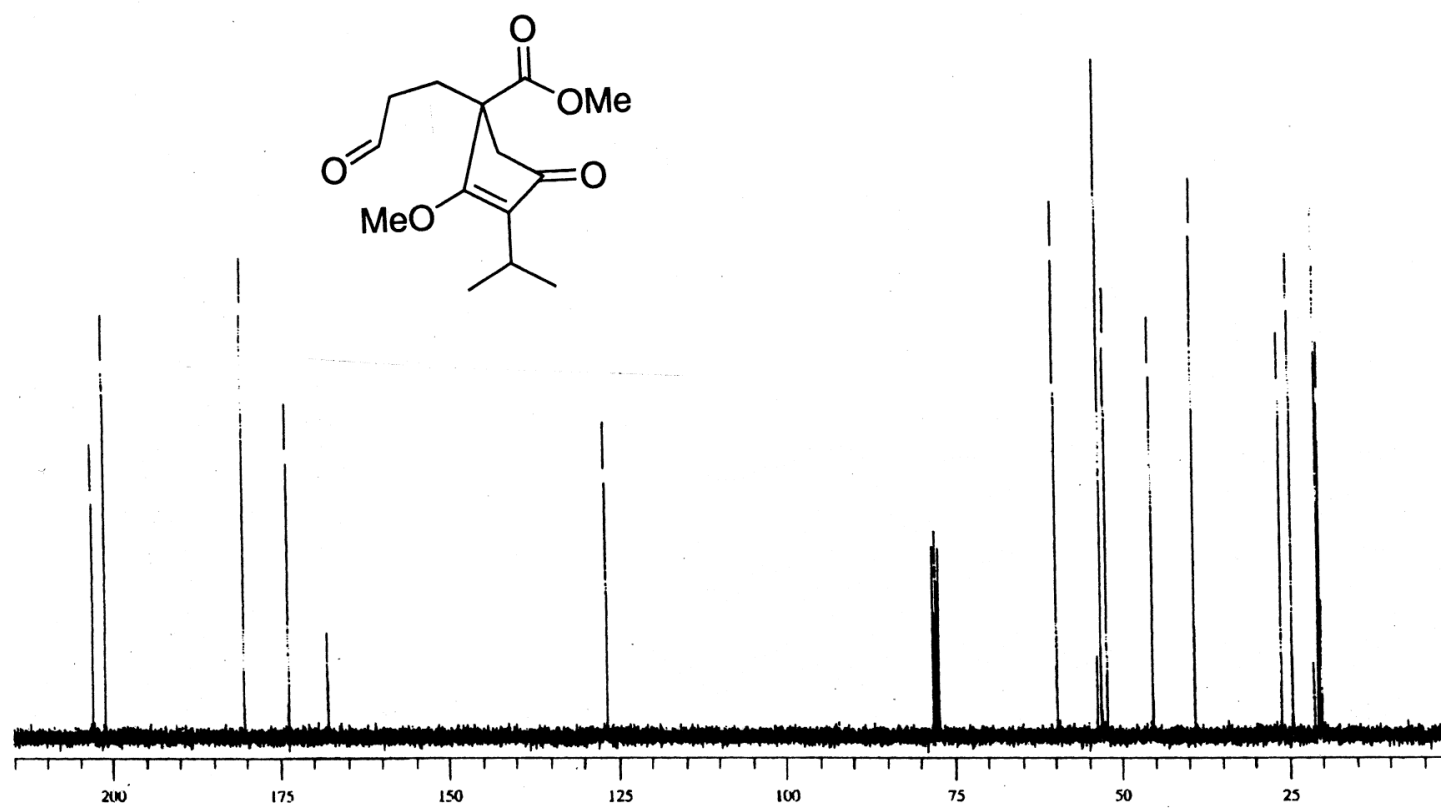

Compound 15 
<smiles>COC(=O)C12CCC(O)C(C(C)C)=C1C(=O)C(C(C)C)=C2C</smiles>

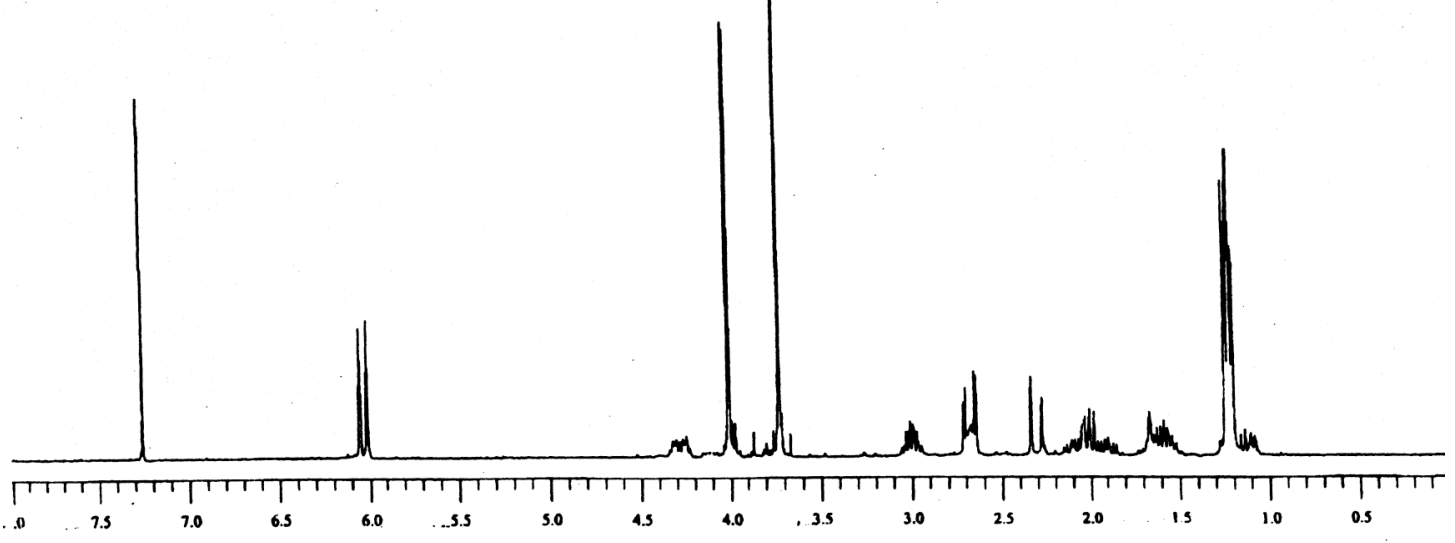

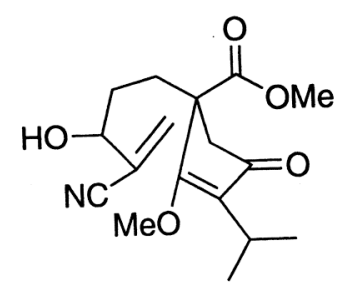

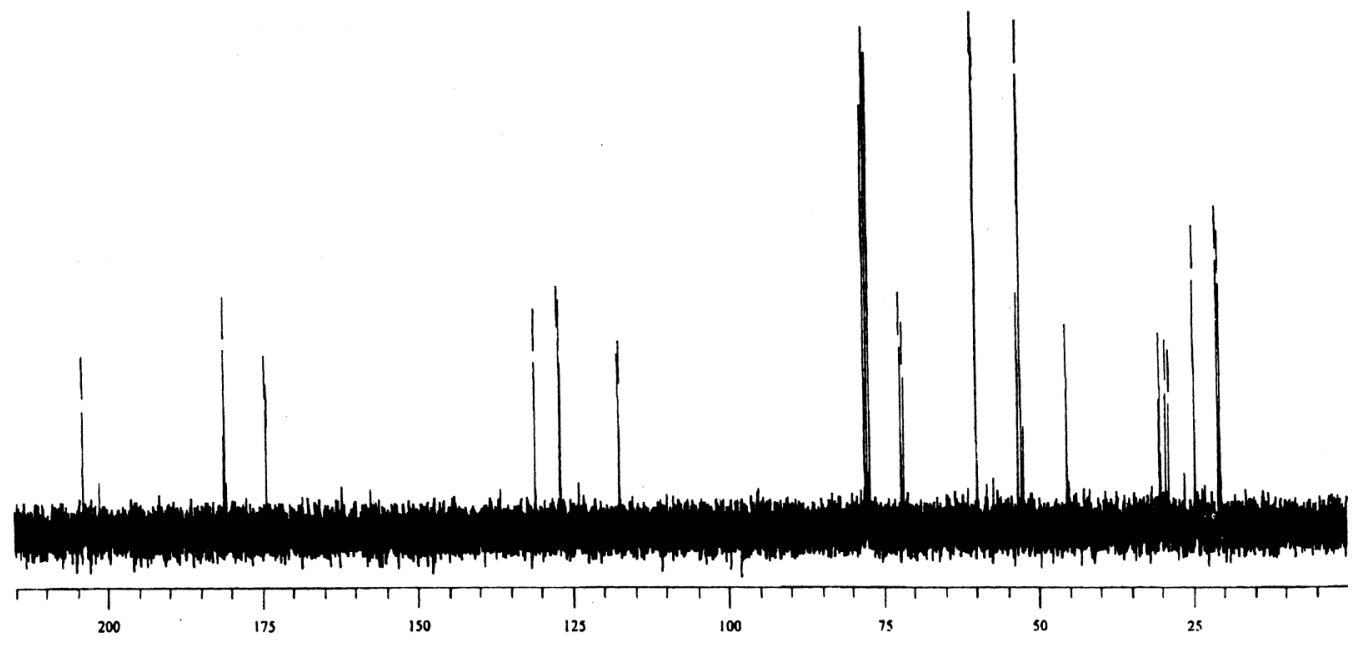

Compound 16 

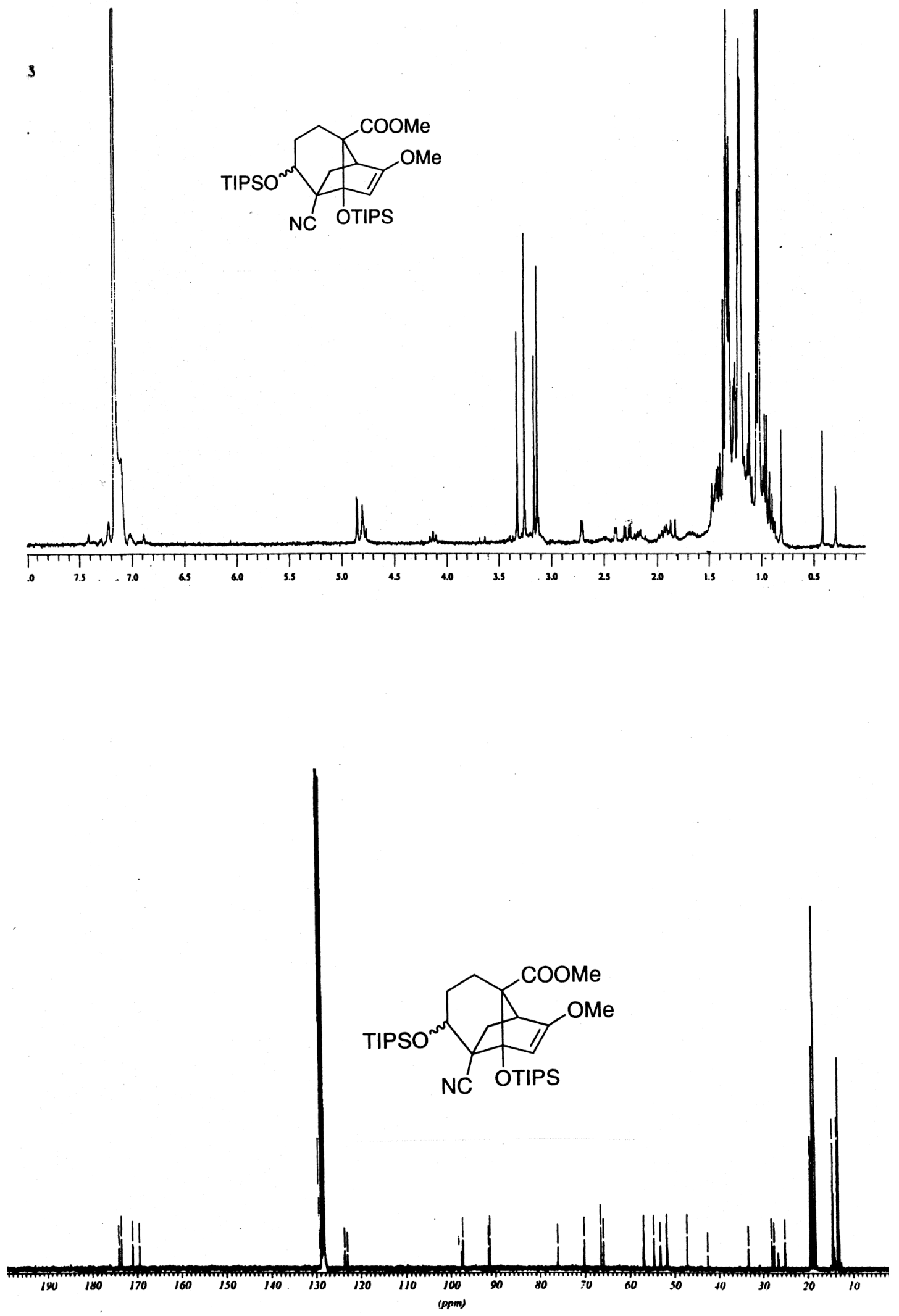

\section{Compound 18}



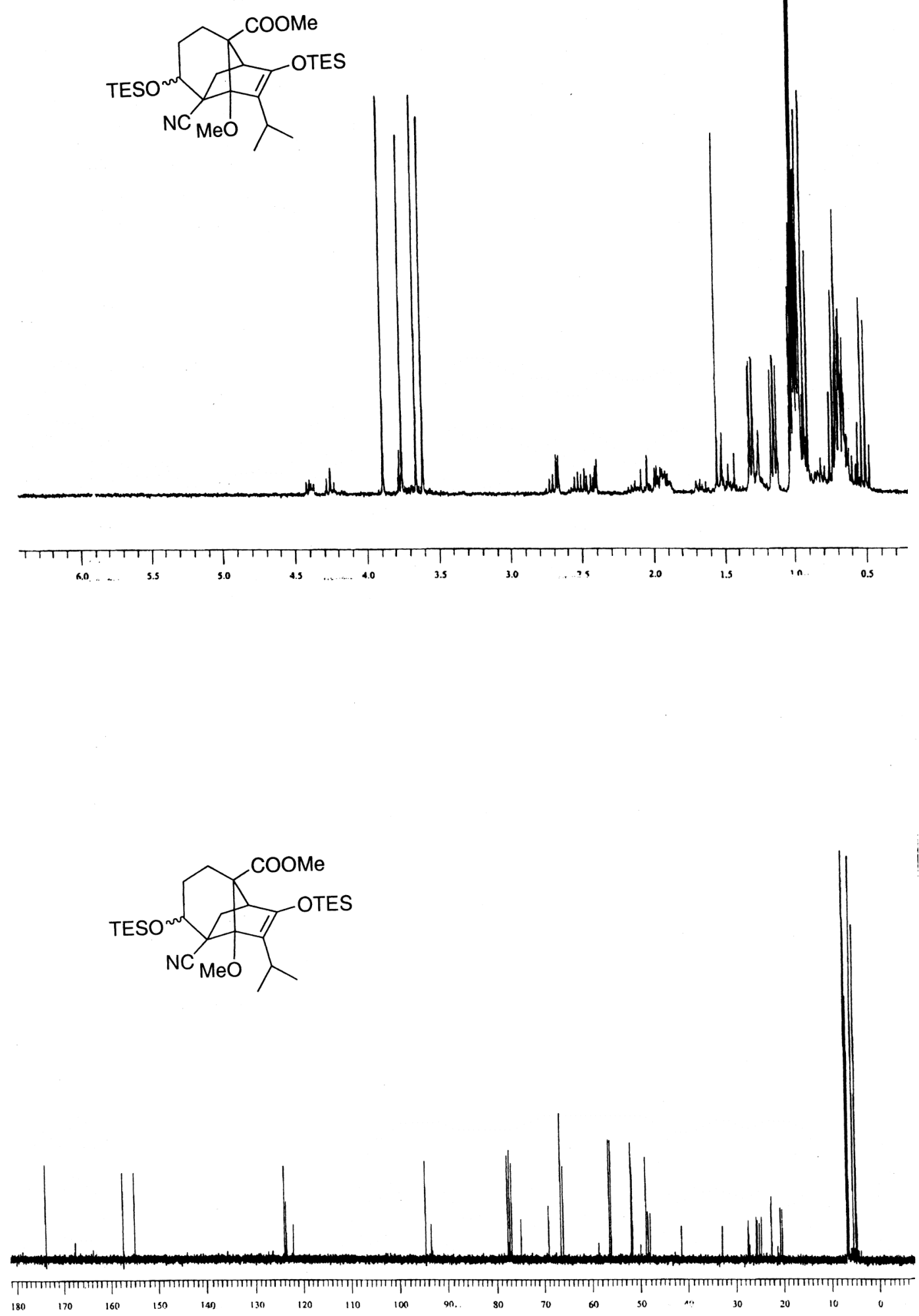

\section{Compound 19}


3
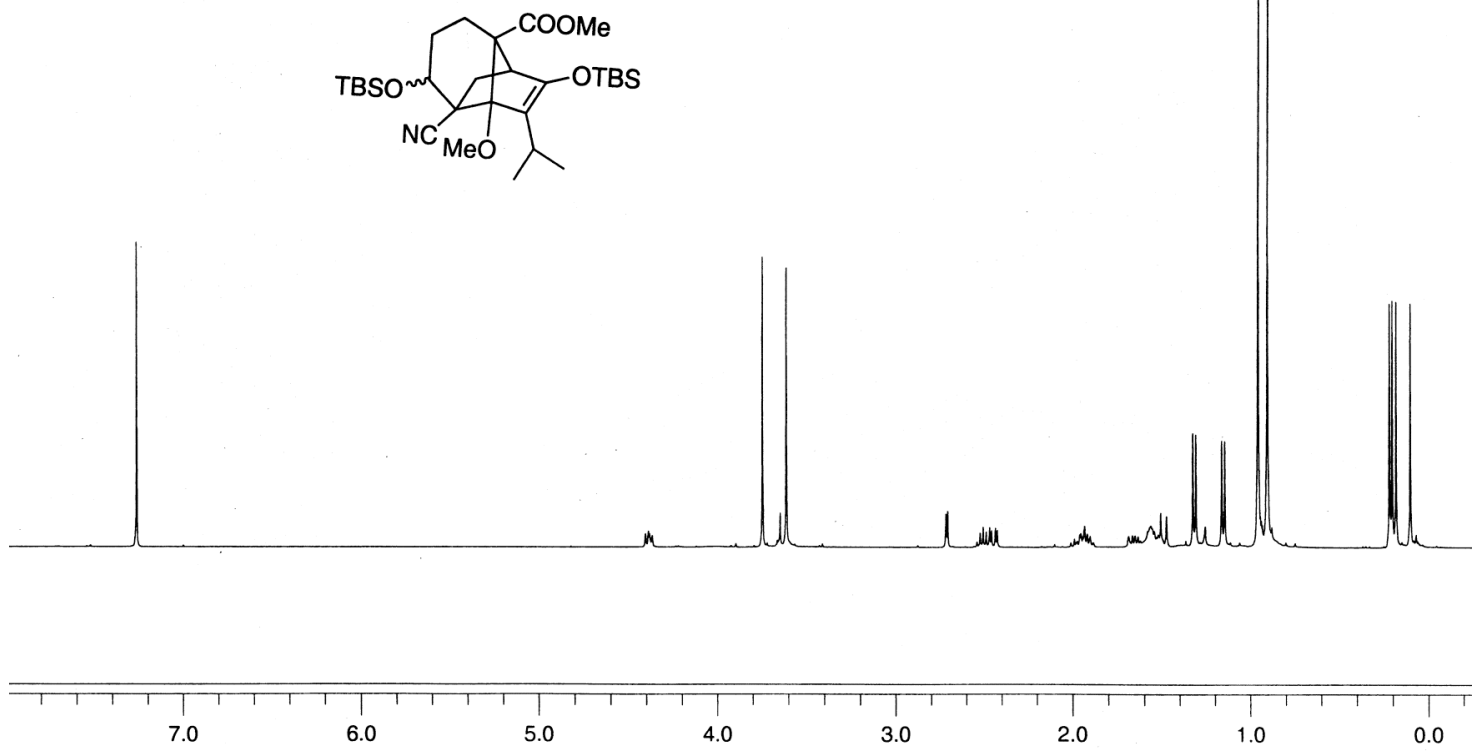

3
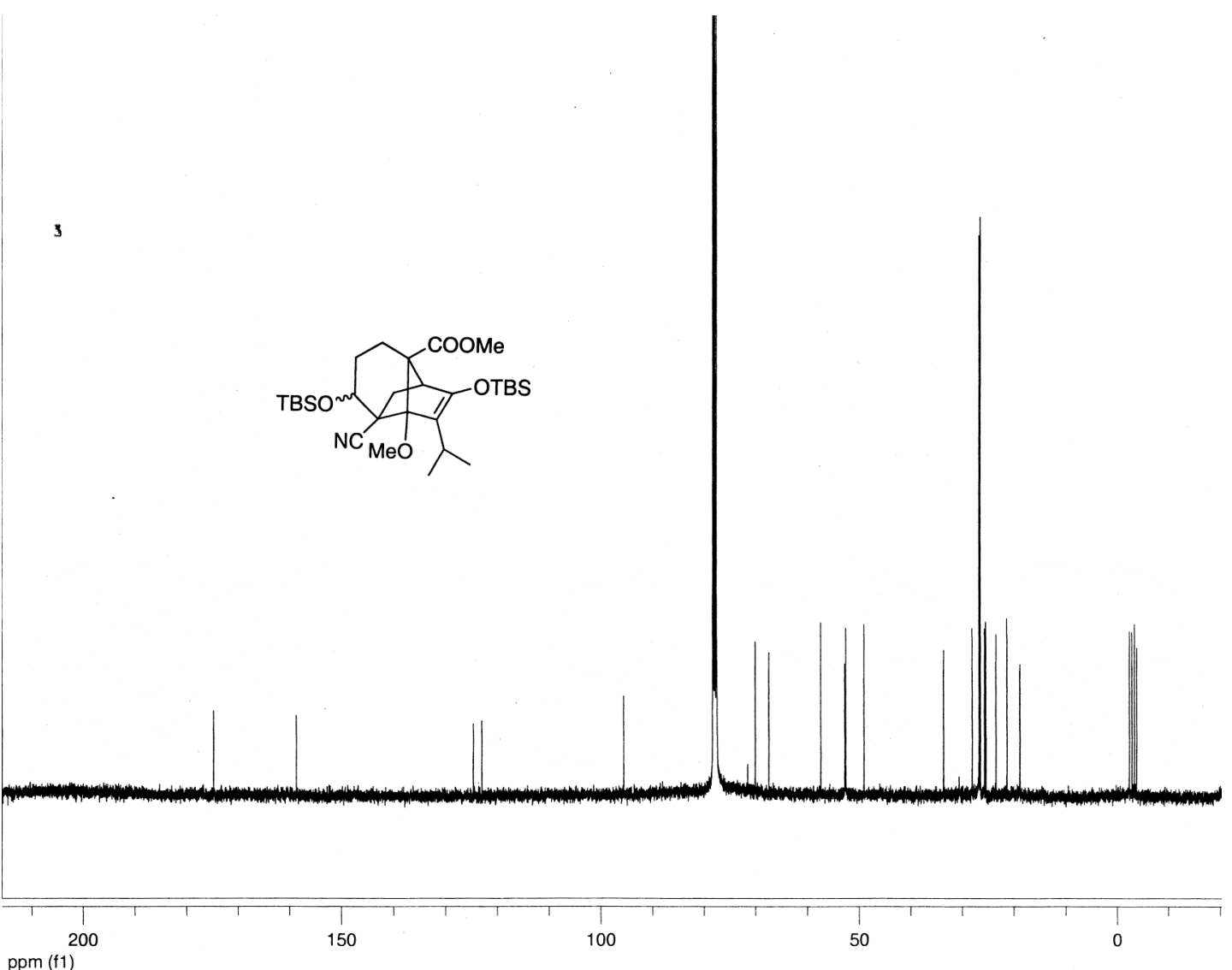

Compound 20 

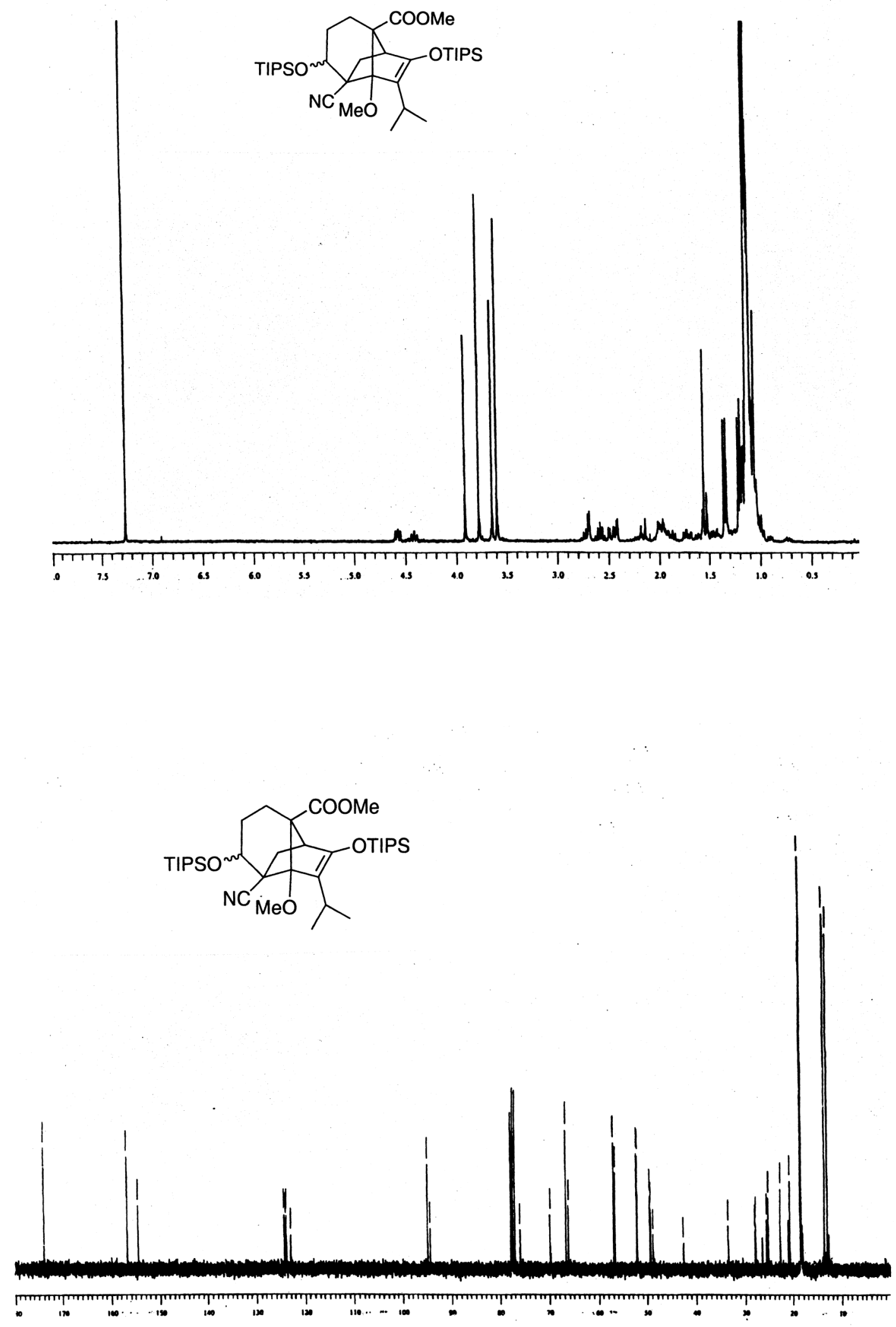

\section{Compound 21}



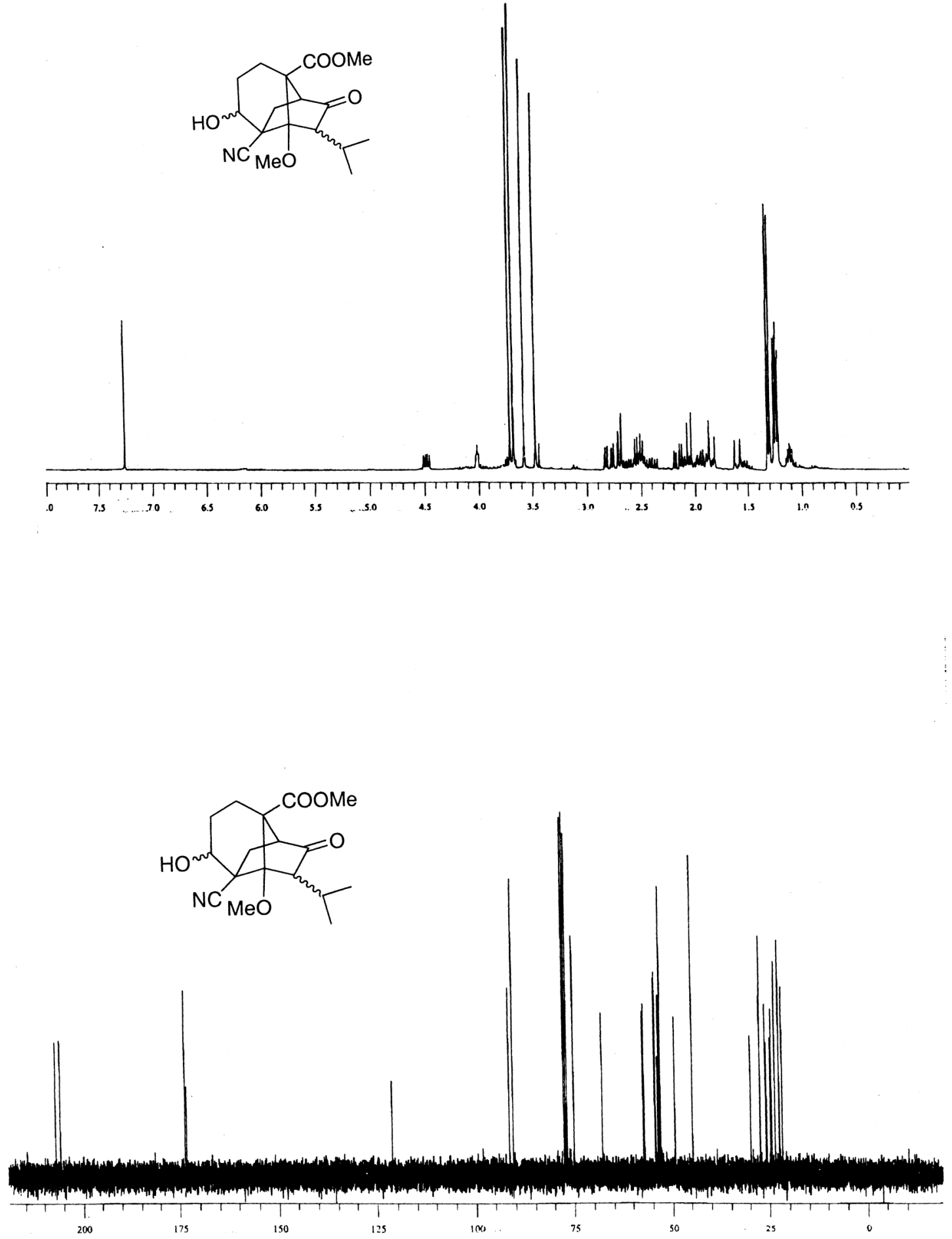

Compound 22 

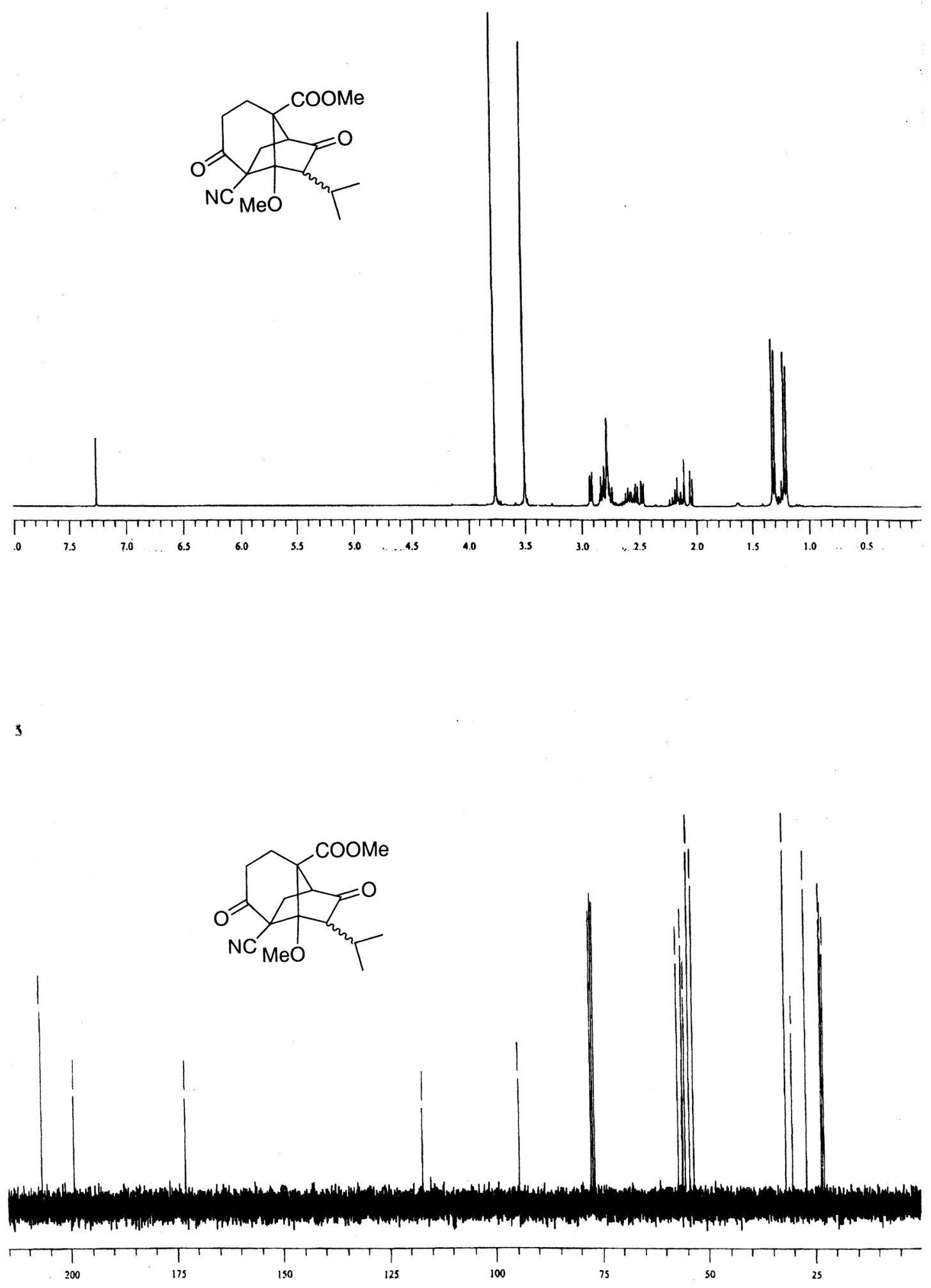

\section{Compound 23}


,
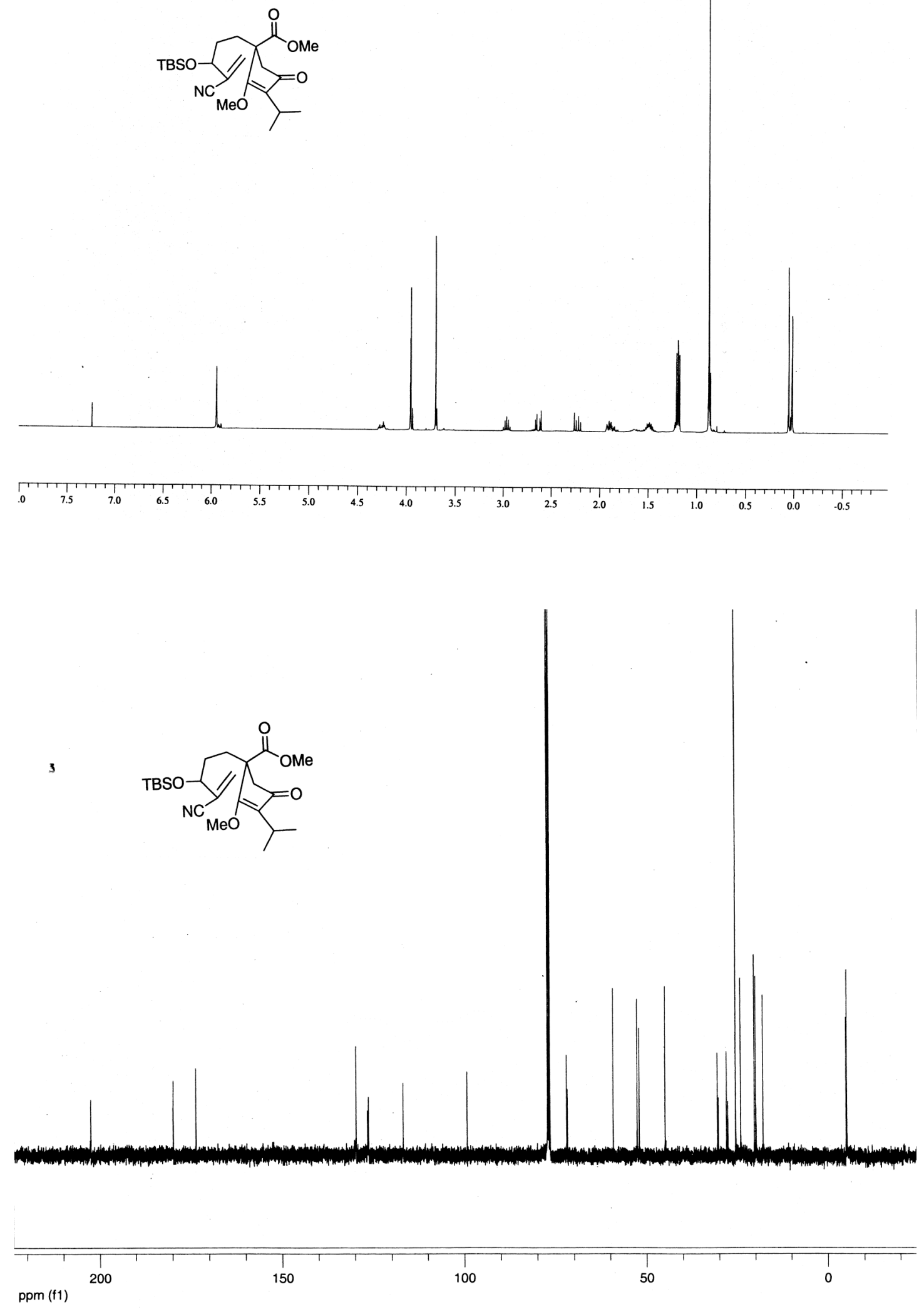

Compound 24 

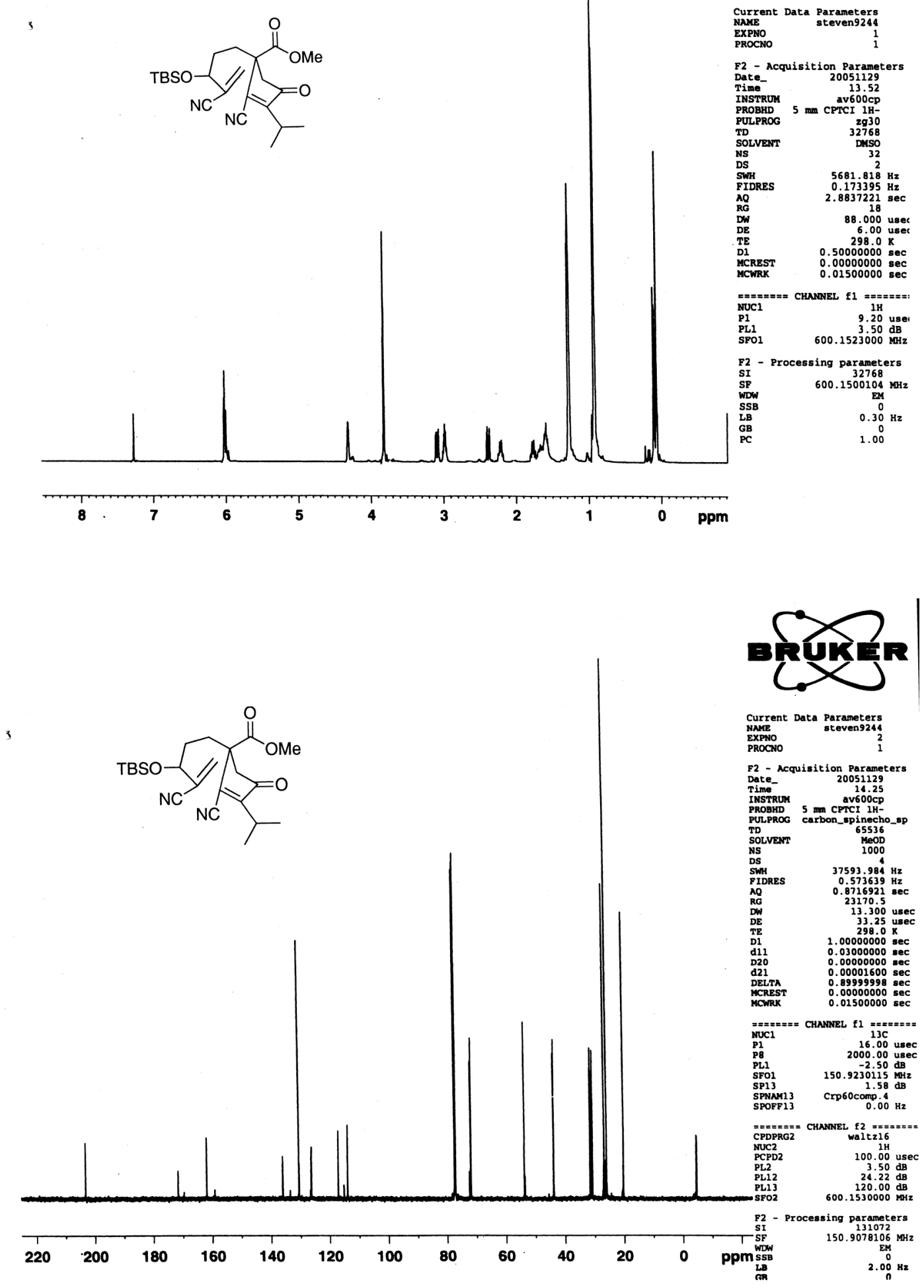

Compound 25 

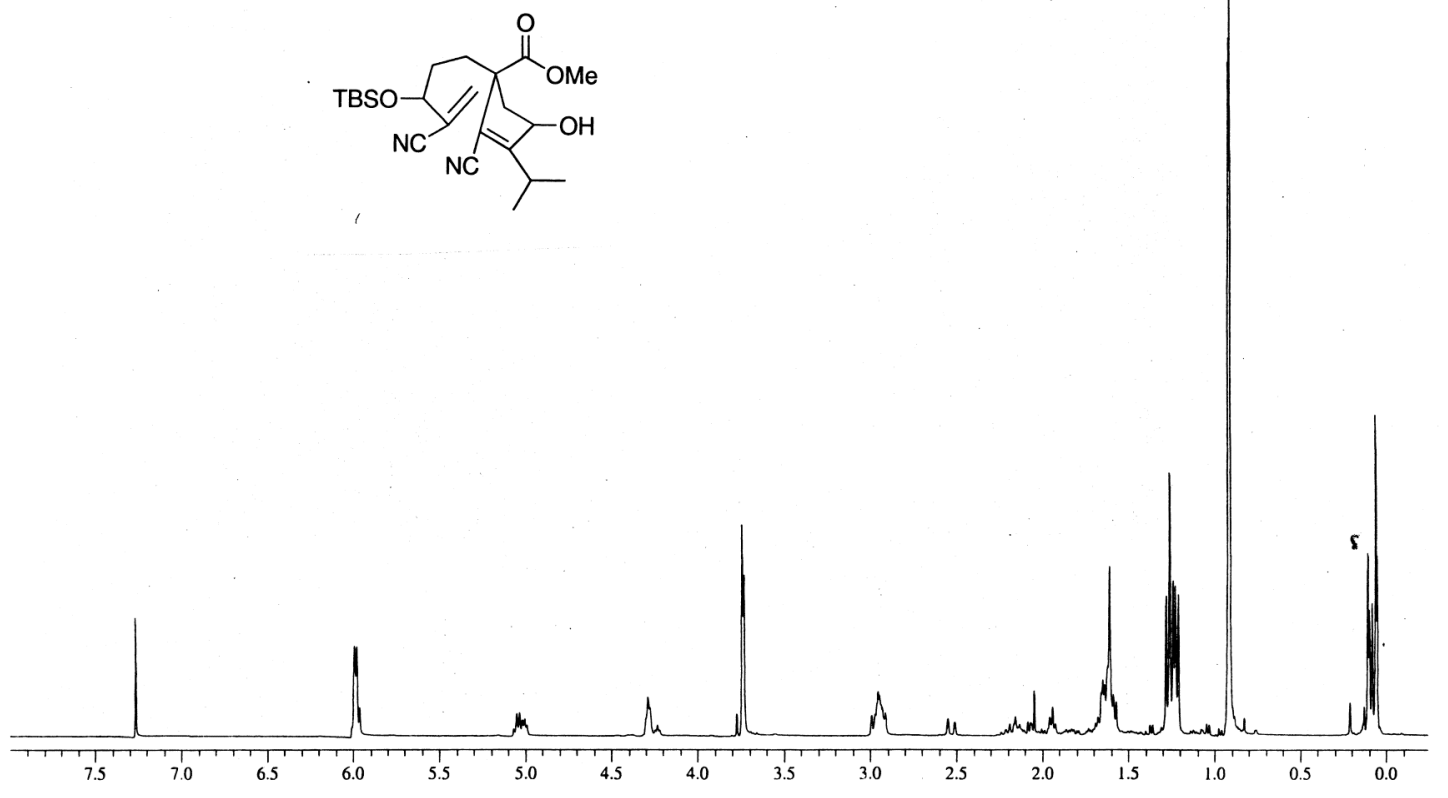

\section{Compound 26}

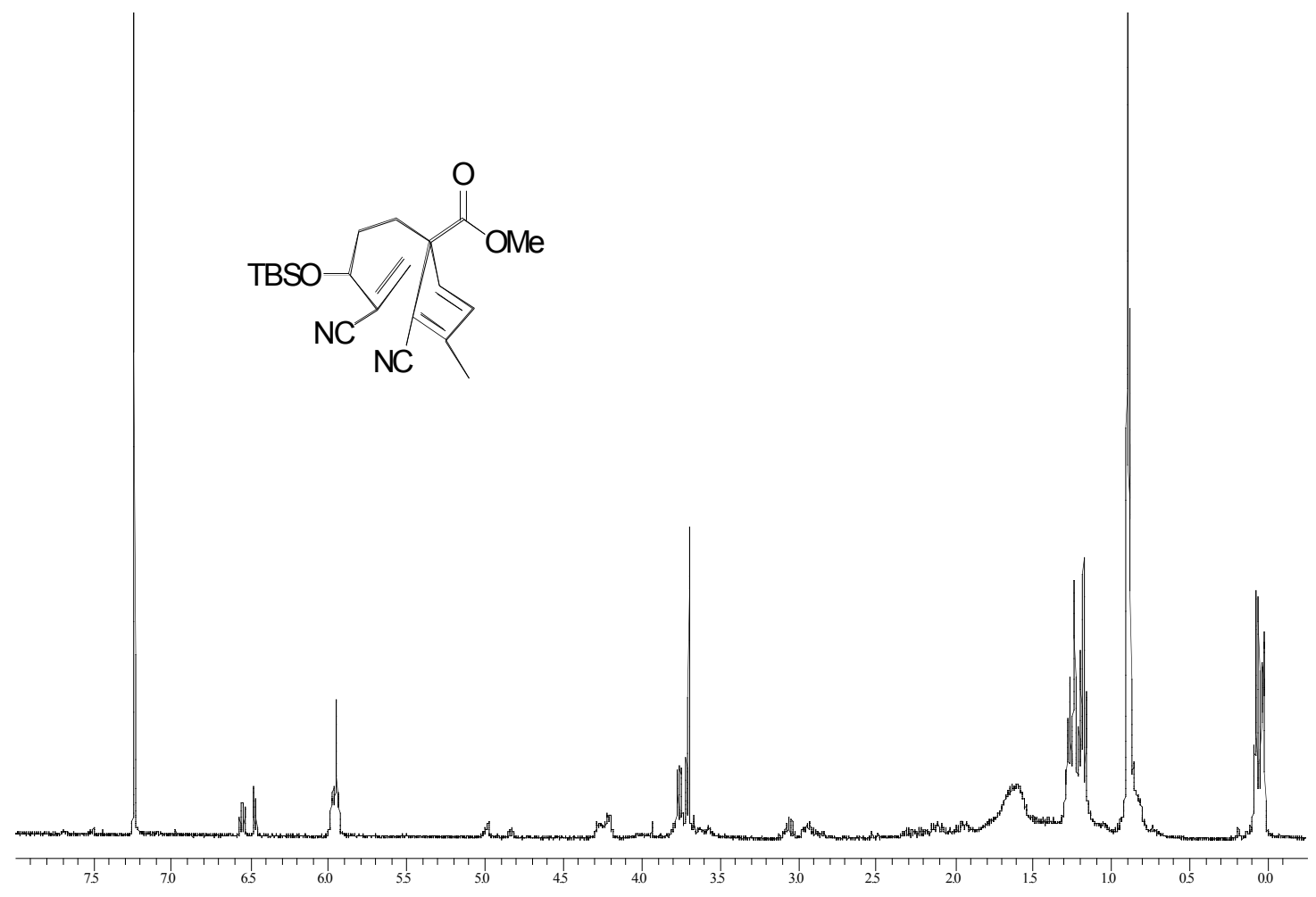

\section{Compound 27}




\section{3}<smiles>COC(=O)C12CCC(OS(C)(C)C)C(C#N)CC1C(=O)C(C(C)C)=C2CN</smiles>

nal

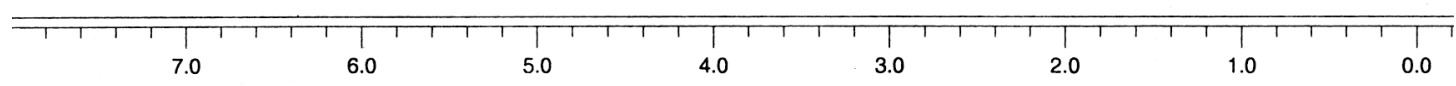

3
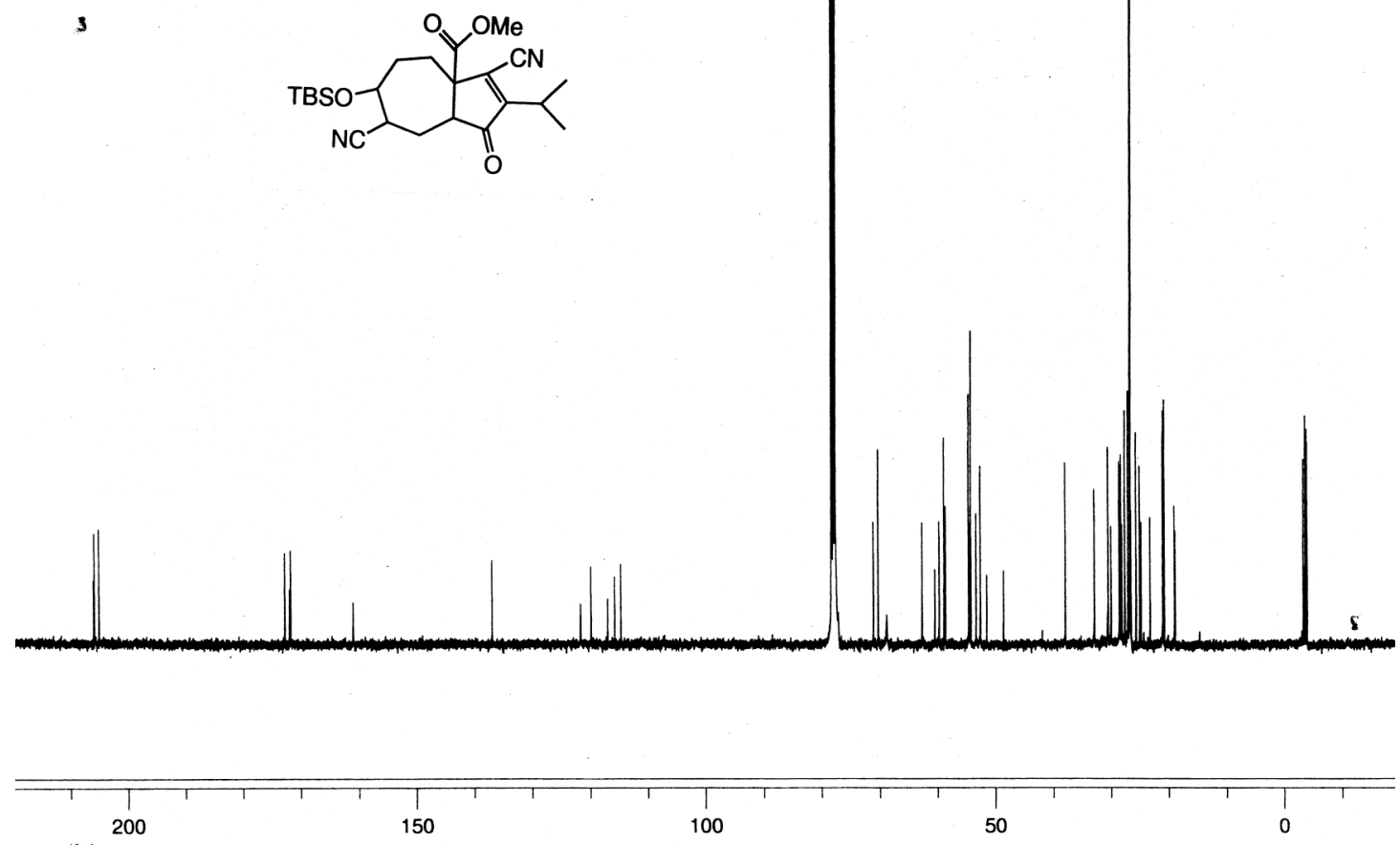

Compound 29 
JOB NO:

$\square 1 \mathrm{H}$ spectrum ref. to $\mathrm{CDCl} 3$ at $7.27 \mathrm{ppm}$
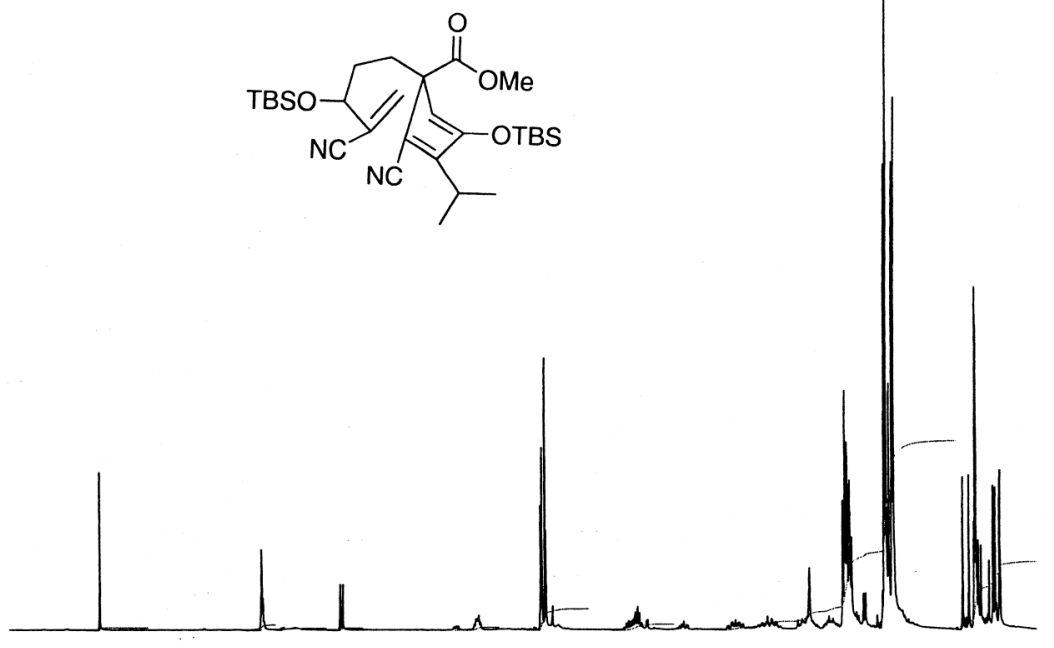

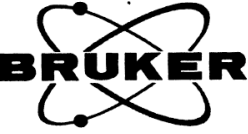

Current Data Parameters
NAME HL-3-40pure (400inv) NAME
ERNO
PROCNO

F2 - Acquisition Parameters

Date
Time

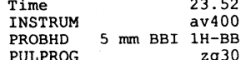

TD

SOLVENT

NS
DS
SWH

SWH $\quad 4990.020 \mathrm{~Hz}$

$\begin{array}{ll}\text { FIDRES } & 0.304567 \mathrm{~Hz} \\ \mathrm{AQ} & 1.6417269 \mathrm{sec}\end{array}$

$\begin{array}{lr}\text { AQ } & 1.6417269 \mathrm{sec} \\ \mathrm{RG} & 10.6 \\ \mathrm{DW} & 100.200 \mathrm{usec} \\ & \end{array}$

$\begin{array}{lr}\mathrm{DE} & 6.00 \mathrm{usec} \\ \mathrm{TE} & 295.8 \mathrm{~K} \\ \mathrm{DE} & 1.0000000 \mathrm{sec}\end{array}$

$\begin{array}{ll}\text { D1 } & 1.00000000 \mathrm{sec} \\ \text { MCREST } & 0.00000000 \\ \text { MCER } & 0.01500000\end{array}$

$======$ CHANNEL $\mathrm{f} 1=======$

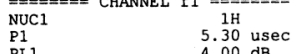

PL1
SF01 $\quad 400.1324008 \mathrm{MHz}$

F2
SI

SF
WDW
SSB

$\begin{array}{ll}\mathrm{SSB} & 0 \\ \mathrm{IB} & 0.10 \mathrm{~Hz} \\ \mathrm{~GB} & 5.00\end{array}$

\section{Compound 30}



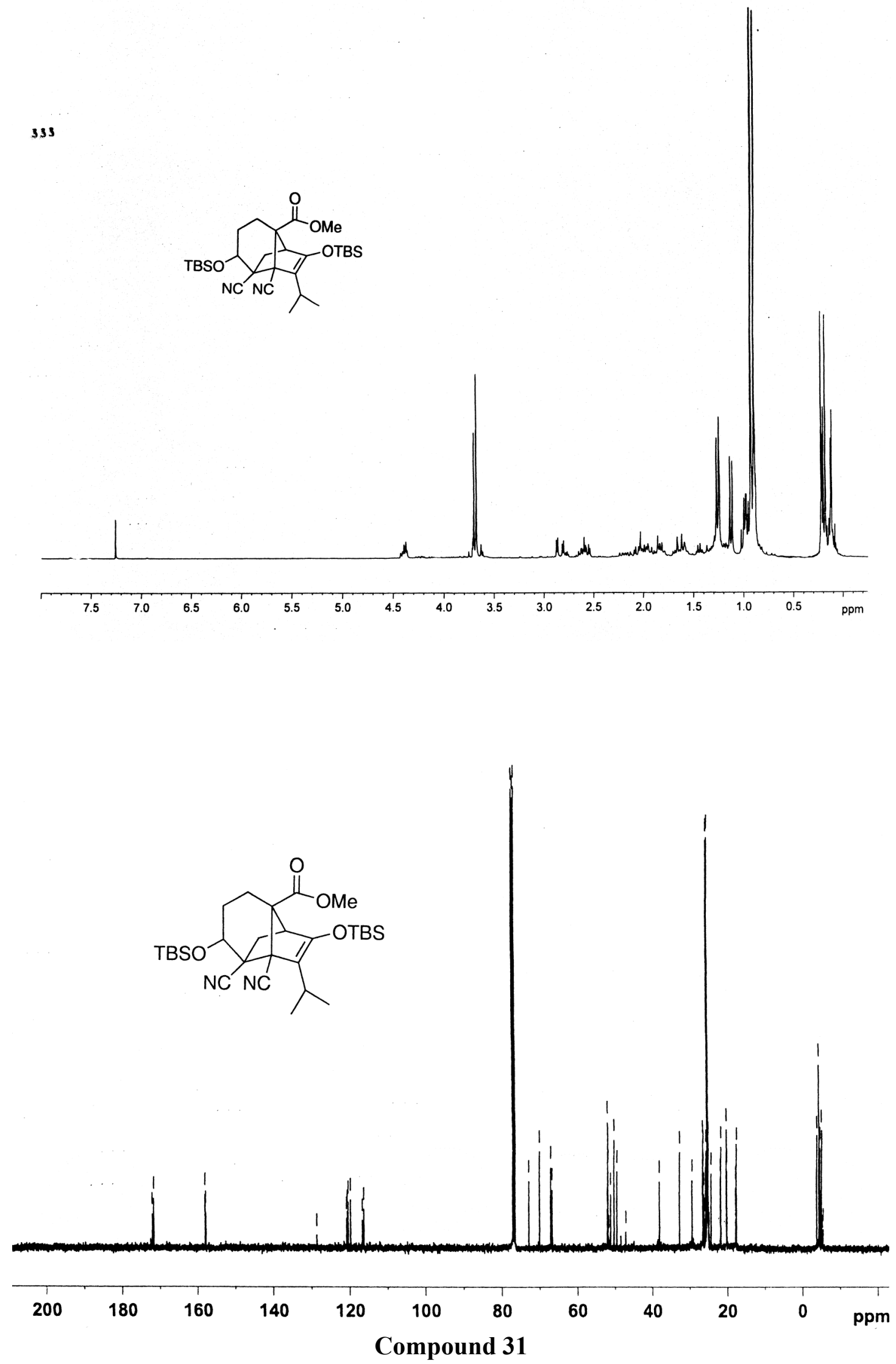
JOB NO:

口1H spectrum ref. to $\operatorname{CDCl} 3$ at $7.27 \mathrm{ppm}$
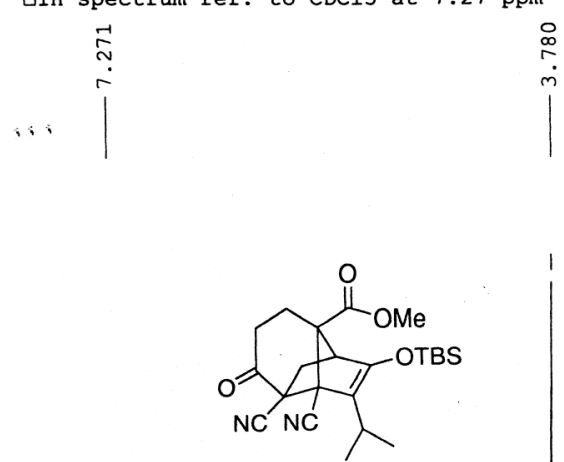

Sample No: 9874 Steven $\mathrm{HL}-3-81 /$, ZD
steven 98742 13C $/$ CDC13

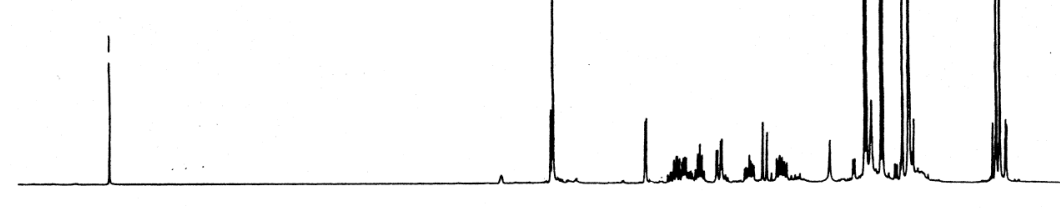

$\begin{array}{llllllllllllllll}7.5 & 7.0 & 6.5 & 6.0 & 5.5 & 5.0 & 4.5 & 4.0 & 3.5 & 3.0 & 2.5 & 2.0 & 1.5 & 1.0 & 0.5 & \mathrm{ppm}\end{array}$

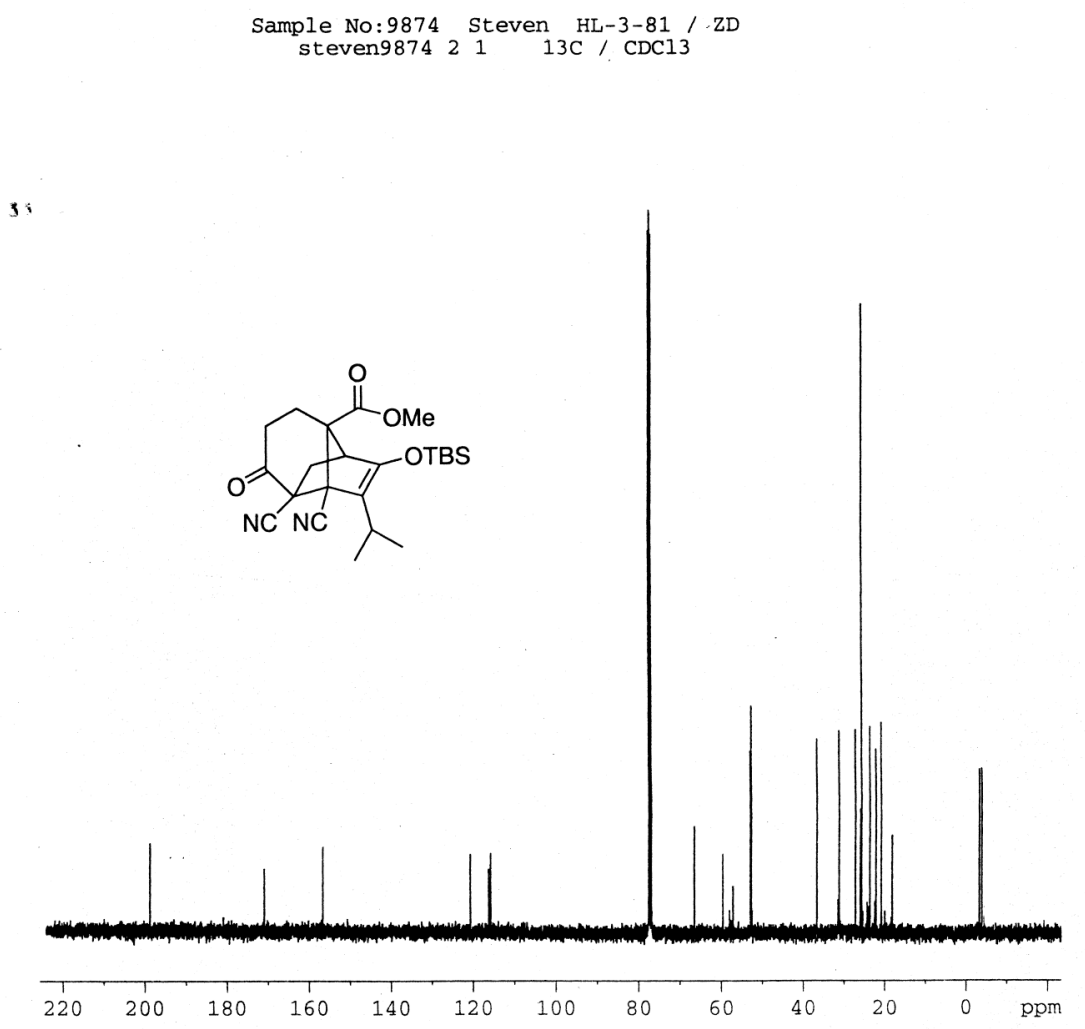

\section{Compound 33}

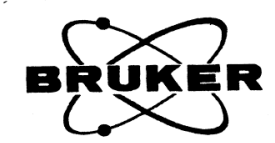

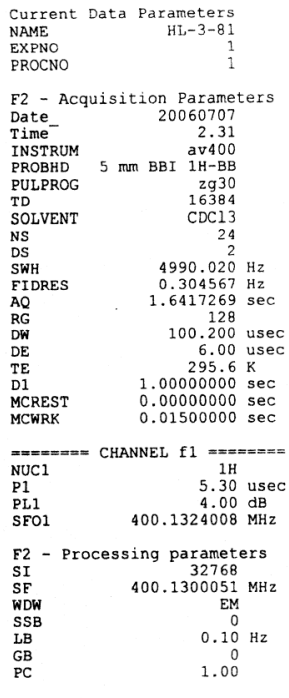

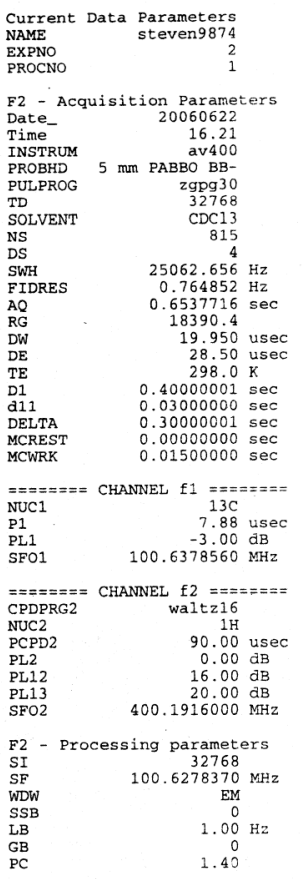

